University of Louisville

ThinkIR: The University of Louisville's Institutional Repository

Electronic Theses and Dissertations

$5-2014$

\title{
A case study of the early institutionalization process of a restorative justice social movement organization.
}

Brittany Buttry-Watson

University of Louisville

Follow this and additional works at: https://ir.library.louisville.edu/etd

Part of the Sociology Commons

\section{Recommended Citation}

Buttry-Watson, Brittany, "A case study of the early institutionalization process of a restorative justice social movement organization." (2014). Electronic Theses and Dissertations. Paper 192.

https://doi.org/10.18297/etd/192

This Master's Thesis is brought to you for free and open access by ThinkIR: The University of Louisville's Institutional Repository. It has been accepted for inclusion in Electronic Theses and Dissertations by an authorized administrator of ThinkIR: The University of Louisville's Institutional Repository. This title appears here courtesy of the author, who has retained all other copyrights. For more information, please contact thinkir@louisville.edu. 


\title{
A CASE STUDY OF THE EARLY INSTITUTIONALIZATION PROCESS OF A RESTORATIVE JUSTICE SOCIAL MOVEMENT ORGANIZATION
}

\author{
By \\ Brittany Buttry-Watson \\ B.A., Psychology/Religion, Greenville College, 2009 \\ B.S., Social Work, Greenville College, 2009 \\ A Thesis \\ Submitted to the Faculty of the \\ College of Arts and Sciences of the University of Louisville \\ In Partial Fulfillment of the Requirements \\ For the Degree of \\ Master of Arts \\ Department of Sociology \\ University of Louisville \\ Louisville, KY
}

May 2014 



\title{
A CASE STUDY OF THE EARLY INSTITUTIONALIZATION PROCESS OF A RESTORATIVE JUSTICE SOCIAL MOVEMENT ORGANIZATION
}

\author{
By \\ Brittany Buttry-Watson \\ B.A., Psychology/Religion, Greenville College, 2009 \\ B.S., Social Work, Greenville College, 2009
}

A Thesis Approved on

April 11, 2014

By the following Thesis Committee

David Roelfs, Thesis Director

Ryan Schroeder, Committee Member

Cherie Dawson-Edwards, Committee Member 


\section{ACKNOWLEDGEMENTS}

I would like to thank all the members of Restorative Justice Louisville who continue to give their time and energy to provide an alternative way to engage young offenders.

Additionally, I would like to thank those who were willing to share their experiences with me and make this research project possible. I am also extremely thankful for the devotion of time, insight, and encouragement from my chair, Dr. Dave Roefls, as well as my committee members, Dr. Ryan Schroeder and Dr. Cherie Dawson-Edwards. Finally, I would not have completed my thesis, nor eaten a healthy meal in the last two years, without the support and confidence of my partner Kyle. I am tremendously grateful to you all. 
ABSTRACT

\title{
A CASE STUDY OF THE EARLY INSTITUTIONALIZATION PROCESS OF A RESTORATIVE JUSTICE SOCIAL MOVEMENT ORGANIZATION
}

\author{
Brittany Buttry-Watson
}

April 11, 2014

This study investigates the early development process of a restorative justice social movement organization in Louisville, KY. Utilizing social movement and organizational frameworks, this case study seeks to expand knowledge on the early developmental period for small, locally founded social movement organizations. Results from this study confirm claims in the literature about the critical nature of an organization's structure, networks, and strategy. The analysis also discovers an unexplored strategy for organizational development, i.e. preemptive co-optation. Restorative Justice Louisville deliberatively sought co-optation by the institution they were attempting to change, the juvenile justice system, from early in their development. Due to this strategy, they were able to quickly develop and build legitimacy with those in the justice system. While bearing in mind the organization is still young, these findings raise questions about the benefits of such a strategy and the implications for other social movement organizations. 


\section{TABLE OF CONTENTS}

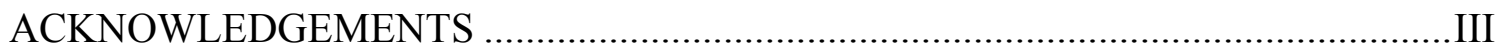

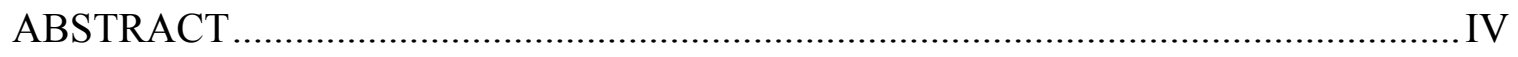

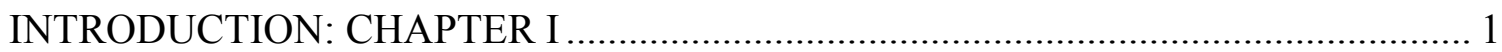

CHAPTER II: REVIEW OF THE LITERATURE …...................................................... 7

THE ReStORATIVE Justice Movement.......................................................................... 8

FACTORS IMPACTING THE DEVELOPMENT OF A SMO .............................................. 11

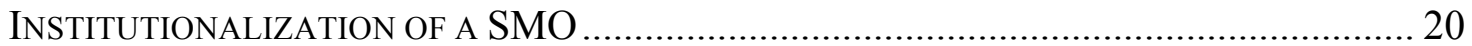

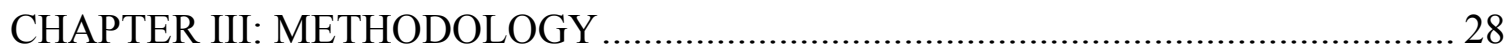

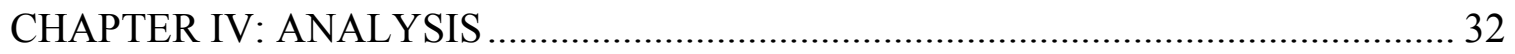

THE EMERGENCE OF ReSTORATIVE JUSTICE LOUISVILLE ……..................................... 32

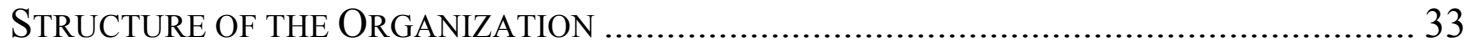

Social Networks LeAding TO THE "Right” PeOPLE .................................................. 39

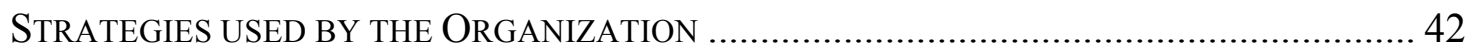

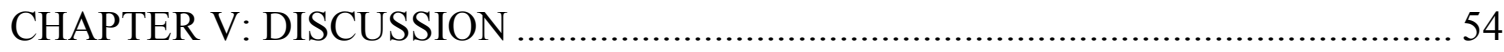

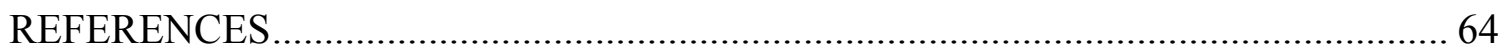

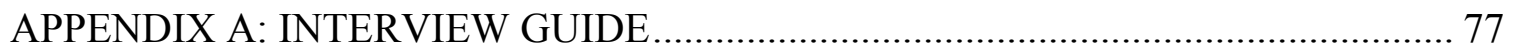

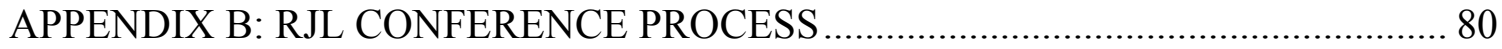

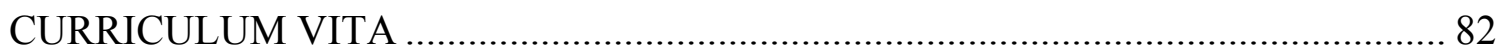




\section{CHAPTER I}

\section{INTRODUCTION}

The strength and consistency of the criminal justice system is an unquestioned reality in the United States and many countries around the world. Beginning in the 1980s and into the $21^{\text {st }}$ century, the "tough-on-crime" approach proliferated in the United States (Calhoun \& Pelech, 2010). Despite widespread findings highlighting the weakness of punitive measures, the public, politicians, and policymakers largely support their continuation (Choi \& Gilbert, 2010). The restorative justice movement emerged quite suddenly in North America, Europe, and the South Pacific in the 1990s as an alternative and a critique to these mainstream retributive and disproportionate sentencing practices (Abrams, Umbreit \& Gordon, 2006; Bolitho, 2012). Restorative justice movement organizations are now found in countless countries and all fifty states in the U.S. (O’Brien, 2000).

One of the early successful models began in New Zealand in response to the disproportionate sentencing of indigenous people and was based on practices from the native Maori tribe (O’Brien \& Bazemore, 2005). As the restorative justice movement diffused throughout the United States, in some locations it joined the victim's movement with the intent of using restorative practices to provide a voice to those who were harmed by a wrongdoing. Other accounts suggest that the movement merged with the larger conflict resolution movement (Zehr, 2004). Though the movement expanded quite 
quickly and gained popularity, it did not have a centralized leadership or mission, which is one reason for its diverse development in different countries and even different states and cities.

There is a fair amount of ambiguity surrounding the specific concept of restorative justice. For instance, it's referred to as a philosophy, theory, model, policy, practice, process, way of life, and of course, some call it a movement. Though there is no sole, established definition of restorative justice, there are consistent principles that distinguish it from conventional western legal philosophy (Johnstone \& Van Ness, 2007). In the last four or five decades, the justice system has expanded and gained control of addressing criminogenic issues (Bazemore, 2001). One of the foundational principles among many supporters is the belief that there are limits to the effectiveness of the state's role in its relationship to crime, and that the community should have a greater stake in maintaining social control. As O'Brien and Bazemore say, "much of the restorative justice agenda implies questions about traditional organizational boundaries of criminal justice and attempts to place more responsibility and resources in the community" (2005, p. 279).

Furthermore, activists find fault in the philosophy the state uses to maintain control. The criminal justice system is built on a retributive model, which "codifies wrongdoings into systems of abstract rules associated with particular consequences, and assumes that wrongs are discrete events to which some true and universal meaning can be assigned" (Calhoun \& Pelech, 2010, p. 288). This model requires a search for facts that supposedly determine a person's innocence or guilt without a shadow of a doubt (Zehr, 
1990) and grants the state power and responsibility to punish them based upon predetermined sentences (Van Ness \& Strong, 1997).

In contrast, the restorative justice movement supports a restorative model, which focuses on offenses as harms conducted against a relationship, rather than the state. Therefore, the responsibility to fix the wrong should be in the hands of the victim, offender, and their support groups and community. The movement seeks to reframe the way our society views and deals with deviance, wrongdoing, conflict and unsatisfactory performance in a multitude of different institutions (Johnstone, 2008). Although it has been integrated in schools and workplaces as a way to deal with conflict and misbehavior, for present purposes, and in the case of many restorative justice social movement organizations (SMOs), the criminal justice system is the institution in focus. A general way to implement restorative justice is to repair a particular harm through an inclusive process, often referred to as a conference between the offender, victim, and community members (Calhoun \& Pelech, 2010; Zehr, 1990, 2002).

The U.S. has relied increasingly on such conferences throughout the past decade, particularly for youth offenders (Abrams et al., 2006). With the growth of this practice, there has been a surge of academic research on restorative justice processes. This research focuses on outcome-based results, questioning the impacts of conferencing on recidivism (Bonta, Wallace-Capretta, Rooney, \& McAnoy, 2002; Bradshaw \& Roseborough, 2005; de Beus \& Rodriguez, 2007; Latimer, Dowden, \& Muise, 2005; Rodriguez, 2004, 2007), participant satisfaction (Abrams et al., 2006; Choi, Green, \& Kapp, 2010; Gal \& Moyal, 2011), and the degree to which such practices restore the wrongdoer to the community (Bolitho, 2012). Little to no research has been conducted, 
however, to examine how these organizations develop and survive. Whether the practices of this method are effective or not, the potential benefits remain unutilized unless SMOs know how to incorporate these practices into society. This is of particular importance because restorative justice is increasingly popular, but debate continues around whether to integrate it with or against the traditional system.

In an effort to contribute to this discussion, the following case study provides an in-depth examination of one social movement organization's experience in the early stages of establishing a restorative justice organization. To do so, I utilize a combination of social movement and organizational frameworks to explore the development of a restorative justice organization in Louisville, Kentucky. The growing body of literature on SMOs focuses disproportionately on large, national organizations (Edwards \& McCarthy, 2004b). The following study seeks to expand our knowledge on how small, locally founded SMOs develop and survive amidst many barriers, focusing on their decisions concerning organizational structure, strategic moves, and use of networks.

Examining a SMO at an earlier stage of their development is an important and underutilized practice. It avoids the bias inherent in only studying organizations with hindsight, where the observer is already aware of the ultimate durability, success, or decay of that specific SMO. Research on SMO strategy in particular "remains susceptible to ad hoc, ex post facto rationalizations by activists and scholars" (Maney, Kutz-Flamenbaum, Rohlinger, \& Goodwin, 2012, p. xiv). The case study at hand is certainly not immune from all such critiques. However, conducting research on participants early in the process allows for capturing a formative account in the midst of the organization's development, opposed to the standard retrospective analysis. 
The present case study employs qualitative methods to gain an understanding of how Restorative Justice Louisville (RJL) developed. I utilize grounded theory techniques to analyze the data. In the findings, the first three categories - structure, networks, and strategy — confirm claims in the literature about what is integral to SMOs' development. As the literature review explains in greater detail, the formality level of an organization, the types of people it mobilizes, and the means they utilize to mobilize people and resources all greatly impact one another and the potential for survival. Along with confirming some aspects of the literature, the analysis uncovers an uncharted strategy for SMO development, preemptive co-optation. The findings reveal that RJL deliberatively sought co-optation by the institution they were attempting to change, the juvenile justice system, from a very early stage in their development. Though it is not clear whether this was the initial design, it is apparent that intentional decisions throughout their development led to this strategy. Because they sought co-optation early, they were able to develop quickly and gain legitimacy and support from those within the justice system. The literature typically speaks of co-optation as a negative prospect, which results in the decline of a SMO and the dilution of its goals. This study defies such expectations, supported by the findings that RJL benefited from their co-optation. While bearing in mind the organization is still in its early stages, these findings raise two questions; what does the strategic use of preemptive co-optation mean for other social movement organizations? Could this strategy be effectively replicated by other SMOs?

Additional research is required to begin to understand the implications for this discovery. Depending on the stance of the SMO, this research could serve as a warning for those organizations that do not wish to become heavily system-integrated and want to 
remain more community-centered. It raises questions about the ways that structure, networks, and strategies converge to set an organization on a particular trajectory, one that may lead to high system involvement, institutionalization and potentially, cooptation.

Chapter two begins by summarizing the key theoretical frameworks and research related to social movement organizations and the history of the restorative justice movement. Chapter three describes the case study and methodology, which includes semi-structured interviews with RJL board members and task force members. In chapter four, I present the results from the interviews. Finally, chapter five explores and discusses my findings and raises new questions for further research. 


\section{CHAPTER II}

\section{REVIEW OF THE LITERATURE}

"Organization is the weapon of the weak in the struggle with the strong" (Michels, [1911] 1962, p. 61-62)

Large-scale, bureaucratic organizations dominate our world (Edwards \& McCarthy, 2004b). These organizations hold considerably more power and influence than individuals. Over the last several decades, this reality has brought an increase of individuals uniting to form social movement organizations to challenge the power of dominant establishments (Edwards \& McCarthy, 2004b; McCarthy \& Zald, 1973). In their 1966 publication, Zald and Ash recognize SMOs as a distinct component of movement mobilization. Their timely introduction coinciding with the general growth of SMOs led to increased awareness that organizational components of movements were critical to procure resources and sustain the movement during times of slowed collective action (Caniglia \& Carmin, 2005).

In an attempt to understand how such SMO's influence conventional power structures, the literature in this relatively young field explores the way they develop into viable change promoting organizations. The following literature review familiarizes the reader with prior work in this area and provides a foundation to understand the organizational development of Restorative Justice Louisville. I begin by providing a more thorough overview of the restorative justice movement. Next, the literature review 
explores mechanisms that theoretically impact development, including decisions about organizational structure, strategic moves, and use of networks. Lastly, but of utmost importance, the review presents the literature on institutionalization and co-optation. It is critical to examine the literature in this area, because it provides a basis for a significant new finding that emerged throughout data collection. While studying RJL's development, it became apparent that their decisions led to preemptive co-optation by the juvenile justice system. While I use this review to introduce the existing literature on the topic and the presence of such a novel strategy emerges in the results section, this subject receives direct consideration in the discussion section.

\section{The Restorative Justice Movement}

As the introductory chapter stated, the emergence of the restorative justice movement does not have a clear origin story. The divergent roots of the movement and the complexity surrounding how to define the concept have led to restorative justice social movement organizations taking a variety of forms (Johnstone \& Van Ness, 2007). For instance, SMOs may pursue any number of the following goals: working for massive justice system overhauls, advocating for a redefining of justice, decreasing case loads for probation officers, supporting the victim rights movement, saving money for the court by providing an additional diversion program, including community members in social control processes, or encouraging offenders to take responsibility for harm caused with the hopes of reducing recidivism rates (Umbreit, Coates, \& Vos, 2007). To accomplish their goals, advocates may remain in the private or not-for-profit sector, intentionally 
keeping distance from the criminal or juvenile justice system, or they may work with the system attempting to change the process from the inside (Umbreit el al., 2007).

In an attempt to provide a more cohesive movement platform in response to the above realities, Johnstone (2008) created a list of five agendas or goals that restorative justice SMOs may be seeking:

1. Promote the use of restorative practices within the social response to crime 2. Encourage a new way of construing crime and related issues and new conceptions of what constitutes a viable solution to these problems

3. Support the use of restorative practices and values in a variety of institutional environments as a form of dealing with deviance, conflict, and unsatisfactory performance

4. Promote restorative justice practices as one aspect of achieving political reconciliation in the aftermath of mass violence and oppression

5. Create a just society, defined as a society in which all humans needs are met, and to transform the way people understand their selves and their relation to the world around them. (p. 61)

The most common and overt objective advanced by restorative justice SMOs, including the organization studied here, is Johnstone's first agenda and surfaces in the form of restorative justice conferences. Conferences are held between the victim and offender, and many times with the guardians and support persons. There is also a facilitator present, who guides and assists the conversation, but largely takes a background role, allowing the participants involved a greater amount of control and leadership. Restorative justice supporters claim, and many scholars agree, that these practices are more productive in attaining the goals of the justice system: decreasing recidivism, keeping offenders accountable, and providing victims and the community a voice in the solution. Others suggest that restorative justice practices accomplish other goals that the criminal and juvenile justice systems do not come close to attaining. For example, allowing people an opportunity to voice their feelings and experiences of what 
happened and how it has impacted their life (Choi, Green, \& Kapp, 2010) and providing an opportunity for healing between the offender and victim (Choi \& Gilbert, 2010).

According to Minkoff's (1993) typology of strategic routes used by SMOs, the implementation of such conferences is considered a "service provision" strategy, "providing direct services or benefits to the constituency without advocating any change in policy" (1993, p. 894). This is the most commonly utilized tactic by restorative justice SMOs. Some groups also utilize institutional advocacy, attempting to challenge the state or elites through legal means. A few groups also engage in the strategy of cultural production or sponsorship, "contributing to the distribution of ideas, knowledge, or systems of belief through action in the arts, media, humanities, or social sciences" (p. 894). Restorative justice SMOs do not often employ social protest or other direct confrontation mechanisms, which composes the last category in Minkoff's typology.

Despite the increased popularity of this alterative form of justice, and the work of scholars like Johnstone to create more comprehensive explanations of the movement, there is still much debate about the way it should relate and work alongside the conventional criminal or juvenile justice system. As mentioned, restorative justice grew in response to the frustration of the traditional system's punitive policies. Though the juvenile justice system has a different history than the adult criminal system, its confessed focus on "rehabilitation" has been fraught with a similar progression towards more punitive, intolerant measures since the 1980's (Bazemore, O’Brien, \& Carey, 2005). For instance, the increased use of zero tolerance policies and the criminalization of disciplinary violations in schools has led to many restorative justice advocates seeking transformation for the juvenile justice system (Bazemore et al., 2005). Many of the early 
and some of the current proponents of restorative justice are anti-institution, intending to create change from outside the criminal or juvenile justice system (Umbreit el al., 2007). But there are others who postulate that if restorative justice remains informal and sporadic, it is unlikely to have the intended impacts (Kurki, 2000). These advocates promote embedding and possibly institutionalizing restorative practices in the system, arguing that it may result in additional attention and support from the larger justice system. While these inquiries remain largely unanswered in policy and academic conversations, the implementation of restorative justice in different locations suggests various solutions to the questions are being put into practice. Similar to many movements, this leads to significant variation in the structure and goals of restorative justice SMOs. The fact that there is such variety increases the need to begin researching their structure and strategies.

There is currently a growing body of literature on restorative justice, but it focuses on the outcomes of restorative justice programs. Research on the establishment and development of these organizations in specific locales is scarce. Though the findings from this case study are not generalizable, they shed light on one organization's ability to embed itself into the juvenile justice system. More specifically, the findings provide insight into an additional approach for SMOs to grow and establish in a particular location.

\section{Factors Impacting the Development of a SMO}

According to McCarthy and Zald (1977), a social movement is "a set of opinions and beliefs in a population which represents preferences for changing some elements of 
the social structure and/or reward distribution of a society" (p. 1217-1218). More specifically, Edwards \& McCarthy (2004a) define SMOs as "named groups of citizens who have, more or less formally, banded together to pursue or resist social change" ( $\mathrm{p}$. 621). Though there is a level of ambiguity concerning the precise distinctions between social movement organizations, civic organizations, interest groups, and nonprofits, the broader restorative justice social movement and the above definition of a SMO by Edward and McCarthy supports the utilization of a SMO framework to analysis Restorative Justice Louisville.

Structure. Due to the tendency of social movement organizations to represent more professional and structured mechanisms of collective mobilization, Resource Mobilization Theory (RMT) has taken center stage in the attempt to explain their emergence, development, and survival. I explain and apply this theory here to examine how an organization's structural decisions impact the development and potential sustainability of a SMO.

In early stages of building RMT, theorists moved away from the notion that social movements were merely irrational masses making demands on the state. The observation that movements were tied to organizations enhanced theorists' perception that they were rational participants collectively acting to change their particular social situations (e.g. McAdam, 1982 and Morris, 1984 for civil rights movement; e.g. Evans, 1980 for women's movement). Researchers discovered that the resources produced through more formal organizing enabled and legitimized social movement mobilization (McCarthy and 
Zald, 1977). Perceiving organizations as a significant technique in mobilization produced new insights about the structure of a movement (Caniglia \& Carmin, 2005).

A central theme in RMT is the necessity of resources for an organization's development (Zald, 1992). Mobilizing resources greatly impacts not only the survival, but also the particular trajectory an organization is able or obligated to follow (Walker \& McCarthy, 2010). Scholarship in this area suggests that the way members of a SMO structure their organization significantly shapes the possibility of accumulating resources (Minkoff, 2002), and at the same time, the organizational structure functions as a resource in itself (Clemens, 1993; Clemens \& Minkoff, 2004). As Clemens claimed, "organizations matter as resources; they make coordinated action possible and success more likely" (1993, p. 770). There are a wide variety of concentrations within the research. Of specific importance to this study is investigating the differences between formal and informal structures, and the impact structural decisions have on the establishment and direction of the organization.

Conversations about organizational structure belong to a long theoretical tradition (Andrews \& Edwards, 2004). Classical organizational research theorizes that to mobilize resources and survive, it is routinely necessary to emulate organizational forms that conform to institutional expectations and norms (DiMaggio \& Powell, 1983; Hannan \& Freeman, 1989; Meyer \& Rowan, 1977). This process is referred to as "institutional isomorphism" (DiMaggio \& Powell, 1983). Isomorphism in this context predicts that organizations progress from informal towards formal organizations. More recent research argues that there are multiple ways for SMOs to develop, varying grades of 
formalization, and development does not inevitably lead to institutionalization or cooptation (Caniglia \& Carmin, 2005; Minkoff, 1993, 1999).

As part of the research to differentiate between formality levels, Staggenborg (1988) identified a pattern similar to for-profit organizations. According to her studies, formalized organizations are more prone to have routinized jobs, a division of labor, hierarchical decision-making, and specified criteria for members. On the other hand, informal organizations more often have a volunteer workforce, relaxed policies, unclear decision-making processes, undetermined policies, adaptable duties, and individual leaders. Gamson created an alternative set of criteria to determine the formality level of a social movement organization. These standards examined whether or not there was (1) a paid staff, (2) a formal written budget, (3) a governing board, (4) official tax-status, and (5) formal incorporation (Edwards, 1994; Edwards and Marullo, 1995).

At the same time that scholars sought to differentiate between formality levels, they also debated the benefits of informal versus formal structures for the establishment of an organization (Piven \& Cloward, 1977; Staggenborg, 1988). A large body of research asserts that formal structures promote an organization's legitimacy. Formal structures are prone to utilize more conventional tactics, which increases legitimacy and reduces the chance of organizational decay (Minkoff, 1993; Staggenborg, 1991). A SMO's legitimacy increases their ability to mobilize resources, and often with less conflict or uncertainty than informal organizations (Gamson, 1990; McCarthy and Zald, 1973, 1977). Such organizational forms are also in a better position to create or respond to openings in political channels (Ferree and Hess, 1985) and more prepared to gain access to diverse networks comprised of allies, authorities, and other potential supporters 
(Tarrow, 1998). Along with these developmental benefits and in part due to these benefits, there is considerable support claiming formal SMOs are more likely to survive (Edwards \& Marullo, 1995). In summary, Clemens and Minkoff find that, "the more organization, the better the prospects for mobilization and success" (2004, p. 155).

Informal organizations, on the other hand, tend to be more adaptable to problems and unintended circumstances, which leads to new opportunities (Gerlach and Hine, 1970; Piven and Cloward, 1977). More inclined to use disruptive tactics (Andrews, 2001), informal organizations profit from the benefits of such demands, which are highly useful in putting pressure on elites (Staggenborg, 1988; Tarrow, 1998). Other scholars contend that informal organizations more frequently remain committed to their original goals and organizational integrity (Piven \& Cloward, 1977).

Networks. Whether a social movement organization is formal or informal, the next critical consideration pertains to the people associated with the organization and its decision-making structure. Relying on RMT, this section presupposes the importance of human resources to mobilization (Edwards \& McCarthy, 2004b). Since Gerlach and Hine's research in 1970, scholarship on movements continues to confirm networks as vital to mobilizing individuals for collective action (Diani \& McAdam, 2003; Kitts, 2000). According to Wang and Soule (2012), networks allow for sharing "information about protest tactics and strategies, newsworthy events of interest, sources of funding, and new ideas for framing movement goals" (p. 1675). Along with accessing resources and information, networks provide channels to other potential supporters to assist in developing SMOs (Obach, 2004; Van Dyke \& McCammon, 2010). 
At times these resources and information are circulated through preexisting networks (Diani \& McAdam, 2003; Edwards \& McCarthy, 2004a). Some theorists consider this co-opting other networks or resources for a purpose other than that for which they were created (Edwards \& McCarthy, 2004b). Research on networks suggests that along with enabling organizational development, they also have the potential to impede long-term success or growth (Edwards \& McCarthy, 2004a). Conversations about the constraining elements of networks often arise when discussing the strength of ties argument (Granoventter, 1973). Weak ties more closely resemble acquaintances and are preferable for facilitating collective action (Ganz, 2000; Strang \& Soule, 1998). Strong ties are connections with friends or people in tight social or professional circles. This logic suggests that weak ties connect an organization to a more diverse network, and thus have an opportunity to gain new information from a wide array of people. Due to the nature of relationships within strong ties, there is more chance of overlap with other people in that network, thus producing repetition in the information received. In their research on Mother's Against Drunk Driving, Edwards and McCarthy explain,

The narrower and more socially isolated the networks, the less useful we would expect them to be in sustaining mobilization...found them [SMOs] much more likely to persist when they had a broader range of ties to other social movement and community organizations in their immediate area. (2004a, p. 624)

When strong ties are the only networks available, they lead to narrow mobilization opportunities, thus constraining growth.

The strength or weakness of ties, and hence the ability to constrain or facilitate mobilization, is not the only consideration. Whether or not the networks lead to the same or to new people, who are the people these networks lead to? What is the status of the people in the networks? Research identifies elite networks as particularly important in 
the development of movements. Influential allies are especially beneficial when located within the particular organization or institution intended for change (Gamson, 1990; Tarrow, 1998). Along with providing access to helpful resources, elite participants also provide legitimacy in the eyes of external audiences and other potential elite supporters (McCarthy \& Zald, 1977; Tilly, 2004). Converted elites can reach out to other elites in their networks to draw more people together. Harold R. Kerbo asserts that "elite power is the power over social networks; convening power specifies the content of that structural advantage...Through these networks, elites are brought together; they then introduce and recruit other elites to join their causes" (as cited in Lindsay, 2008, p. 75). Elites greatest power, rather than influencing legislation or changing policy, is their "convening" power (Lindsay, 2008).

Strategies. Amassing resources and achieving entry into networks does not, of course, inevitably lead to efficient or effective use of resources or the immediate conversion of those networks. Organization strategy is a crucial factor in determining how to use the resources and convince people of the cause. According to Minkoff, "action strategy is the most salient feature in determining organizational life chances" (1993, p. 890). Strategic choices have the power to significantly modify the trajectory of a group (Wang \& Soule, 2012). Therefore, along with an organization's network and structure, the literature addresses how strategies significantly impact a social movement's growth and/or survival. Examining organizational strategy continues to be an important part of RMT, which highlights the way strategic decisions impact structure, goals, and access to resources (Button, 1989; Freeman, 1979; Gamson, 1990; Schram \& Turbett, 
1983). The ensuing section speaks to the importance of furthering research on strategic action, mentions the different kinds of strategy, introduces frames as a part of strategic design, and lastly, presents the search for legitimacy as part of the strategic plan.

Discussing an organization's strategy not only allows the reader to see the degree of agency involved in the process of movement development (Jasper, 2004), but it also opens up opportunities to create links between scholarship on social movements and application for activists (Maney et al., 2012). An increasing number of researchers are emphasizing the need for studies that offer applicable findings for social movements (Bevington \& Dixon, 2005). This is a gap in the social science literature across the board, but it is a significant discrepancy in the social movement literature. An organization's structure provides a form for collective action and networks are key in accessing participants and supporters. Strategy, however, is where ongoing decisionmaking and goal formation are located, which makes it a clever place for convergence between scholars and practitioners (Maney et al., 2012). While contributing to literature on how organizations develop, this work may also be useful to activists, either in restorative justice or in other movements, to provide practical information on the options and impacts of strategic planning. Studies on movements need to provide activists practical ways to utilize the research on the social movements in which they are dedicated. Utilizing the literature on strategy is a prospective way to work towards this ambition.

According to some, the success of a social movement organization relies on the strategy and tactics appealing to as many people as possible (Soule, 1997, 1999; Soule \& King, 2008). When considering the diversity of strategic options, it is common for 
theorists to differentiate between organizations that employ radical means from those who utilize conventional, less disruptive means. As previously mentioned, more formal or professional organizations tend to choose less disruptive and more institutionalized tactics. Informal groups tend to choose more disruptive or direct tactics. Though a debate exists surrounding the benefits of each option, when the goal of an organization is to seek institutional acceptance, their strategies tend to follow a certain trajectory. Findings more often conclude that institutional acceptance is put at risk when confrontational tactics are utilized (Minkoff, 1993).

A growing body of social movement research considers the use of frames as a strategy. According to Snow, framing processes are "conscious strategic efforts by groups of people to fashion shared understandings of the world and of themselves that legitimate and motivate collective action" (as cited by McAdam, McCarthy, \& Zald, 1996, p. 6). The concept of framing contributes greatly to understanding collective identity construction and is also used as a way to produce support from potential participants (Benford, 1997; Benford and Snow, 2000; Gamson, 1995). Social movement organizations often frame their claims with the goal of aligning the movement with preexisting cultural values and beliefs held by those they hope to convince or mobilize (e.g. Liévanos, 2012; Lounsbury, Ventresca, \& Hirsch, 2003; Snow \& Benford, 1988; Snow, Rochford, Worden \& Benford, 1986;). Frames are used to build legitimacy, increase appeal to the cause, and produce resonance of the cause with the public and decision-makers.

The idea of framing is very closely aligned with the search for legitimacy. As the previous pages indicated, an organization's legitimacy is crucial and interconnected with 
many other aspects of organizational development. Generally, following institutional norms increases a SMO’s legitimacy (Walker \& McCarthy, 2010). Following such norms occurs more often in formal structures, where participants tend to utilize conventional tactics, which also aids in the production of legitimacy. Finally, the particular people sought through the networks can be crucial in the pursuit of legitimacy. Though I have made these points elsewhere, the search for legitimacy warrants a brief reference of its own, specifically as a strategic choice. Suchmans's commonly cited definition of legitimacy is "a generalized perception or assumption that the actions of an entity are desirable, proper, or appropriate within some socially constructed system of norms, values, beliefs, and definitions" (1995, p. 574). Walker and McCarthy's research indicates that the active endeavor to produce legitimacy for an organization can indirectly diminish the risk of failure (2010). This suggests that producing legitimacy is not only an integral part of organizational development, but also one that is a strategic decision.

\section{Institutionalization of a SMO}

Theoretical framing. Works from both the institutionalization and co-optation perspectives greatly expand our knowledge on the relationship between social movement organizations and the institution they seek to challenge. This section builds a foundation for discerning the results section and demonstrates gaps in the literature for the possible uses of co-optation by social movement organizations. Such a conversation may seem like merely an attempt to exhaust the literature surrounding SMO's developmental process. Due to the unique development of the present case study, however, discussing this area of research is critical. As emerges in the analysis, RJL introduces a new 
strategic approach to develop inside a more powerful institution, in this case the juvenile justice system.

The growth of SMOs in practice, and subsequently in theory, has led to observations about the similarities between non-movement organizations and movement organizations. As mentioned in the previous section on structure, SMOs can range in their level of formality, but generally represent the more organized and formal division of a movement. Research suggests that even when organizations begin as informal structures, they often progress towards greater levels of formality. These realities have inspired proposals that SMOs follow a similar rational progression towards bureaucratic, institutionalized structures. Such considerations suppose institutional myths are at work on SMOs in the same as they would any organization.

The classical view founded on works from the Weber and Michel tradition suggests that in order to survive, movements become progressively rational and institutionalized, and therefore more conservative in their ideals. According to Meyer and Rowan, formal organizational structures surface as reflections of "rationalized institutional rules," rather than reflecting the demands of their specific work place (1977, p. 340). These institutional rules or norms serve as myths that organizations largely incorporate to gain increased prospects of survival, stability, legitimacy, and resources. This process often happens whether or not it aids the effectiveness of the internal activities of the organization. DiMaggio and Powell (1983) applied Weber's notion of the progression towards rationalization to discuss the homogeneity of organizations. Institutional isomorphism produces organizations that look and act a certain way, resulting at times in organizations changing or giving up certain values or goals in order 
to follow the established patterns. This process introduces the next possible outcome. There are occasions when the advancement towards formality and institutionalization is not the end of the story.

Classical theorists proposed that the progression towards rationally structured social movement organizations could lead to conventional institutions co-opting and subverting the initial goals of movements (Selznick, [1949] 1965; Michels, [1911] 1962). More recent scholarship disputes the claim that bureaucratization is an inevitable outcome, asserting that there is considerable heterogeneity in organizational forms (Clemens, 1993; Jenkins, 1977; Minkoff, 1999; Rucht, 1999; Voss and Sherman, 2000; Zald \& Ash, 1966). Regardless of the debate, there is widespread agreement that when movements do progress towards institutionalization, their alternative ideals and goals are modified to maintain the established institution (Morrill, 2006) and they may become coopted by the established institution (Coy \& Hedeen, 2005; Osterman, 2006). The mainline assumption in the literature is that the gradual move towards institutionalization and possibly co-optation, when it does occur, leads to the demise of a movement (Blumer, 1969; Mauss, 1975; Osterman, 2006; Tilly, 1978; Zald \& Ash, 1966). Accordingly, many researchers and activists perceive co-optation as a blunting of challenger movements (Coy \& Hedeen, 2005; Piven \& Cloward, 1977). In their research on the community mediation movement, Coy and Hedeen (2005) apply DiMaggio and Powell's (1983) concept of coercive isomorphism to create a process model of cooptation. They define this term as the "influential role of powerful exogenous institutions and resource providers, particularly the state, in fostering or imposing the reproduction of organizational patterns and values that reinforce the status quo" (p. 408). 
Coy and Hedeen's process model of co-optation starts like many social movements begin, with the challenging movement addressing a problem, demanding change, establishing alternative institutions to the one that they are stating is the problem, and the state or challenged institution recognizing the movement's demands. The second phase occurs as the challenged institution appropriates the language the challenging movement is demanding, but dismisses the larger values. In this process the institution invites the challengers into the policy-making discussions, while redefining the challenger's terms. The challengers perceive this acceptance as a positive step towards power sharing and the prospect of institutionalization appears attractive for the purposes of building legitimacy and mobilizing resources. In the third stage, the challenged entity creates or sponsors parallel in-house programs and calls on movement activists to lead the initiative, assimilating the leaders to their reform project. In the second half of the third stage, the program is transformed and the challenged institution sets priorities and goals, which the movement must restructure to meet. In the final stage of the model, the priorities and goals become routinized into standard processes and even legislative regulations. Then the clients or consumers of the program develop particular expectations aligned with these standards. At this point, the challenging movement may itself create an institution to support, maintain, and protect the goals they now have. This process is co-optation. Many activists and social movement scholars question the devastating effects this process has on movement goals and integrity.

This conversation presents an irony in the literature on organizational rationalization (Clemens, 1993). Formalization and routinization increases an organization's chances for resource mobilization, legitimacy, and survival, but at the 
same time increases the risk of co-optation and hence the dismantling of the movement (Andrews, 2001; Edwards, 1994; Edwards \& Marullo, 1995; Minkoff, 1993, 2002; Walker \& McCarthy, 2010). As Clemens articulates, "Hierarchical bureaucratic organization is necessary to compete effectively in the formal political arena, yet the processes of competition and organization distance the leadership from the interests of their followers and from the organization's initial commitment to the transformation of the political system" (1993, p. 764). There is no straightforward way for a social movement organization to sidestep this irony; activists have choices to make about how to establish their organization in the midst of these complexities. The question of choice introduces the importance of agency into this conversation.

Role of agency. In an attempt to avoid institutional determinism, I also consider the role of agency. Despite the classical institutionalist theory that bureaucratization or formality is inevitable, it is increasingly common to study the agency involved in organizational decisions, for both social movement scholars (Jasper, 2004; McCarthy \& Wolfson, 1996) and organizational institutionalism scholars (Beckert, 1999; Hwang \& Powell, 2005; Maguire, Hardy, \& Lawrence, 2004). The most common agent in the discussion of co-optation is assumed to be the larger institutional or governmental body involved. I am interested here, however, in the agency of the movement participants. In the following few pages, I review the literature with an alternative question in mind: is it ever the intention of the challenging movement to become institutionalized or co-opted as a strategy to advance their goal? 
First, it needs to be noted that the search for legitimacy, resources, and formality, which has already been discussed, will not be the focus of this conversation. Though these are clearly signs of deliberate action made by movement members, this section is focusing on decisions approaching institutionalization and co-optation. One area related to these questions that blatantly discusses movement participant's agency is institutional activism, also referred to as insider status. This strategy involves movement activists making their way into the institution they are attempting to change and working for the cause from within. Such an approach is seen in the civil rights movement, the women's movement, and the battered women's movement (Banaszak, 2005; Gagne, 1996; Santoro $\&$ McGuire, 1997). In each of these movements, there were occasions where members would seek political or professional positions for the purpose of using their status and position to work for the benefit of a movement. Several scholars suggest that over the last few decades there has been an increase of activism happening within the institution, distorting the previous well-defined distinctions between insiders and outsiders (Jenness, 2005; Katzenstein, 1998; Taylor, 2007). Santoro and McGuire (1997) argue that insider strategies can be more effective than those attempting to work outside the system. Due to the "Increasing rationalization, routinization, centralization, and corporatism in U.S. social and economic life" (Coy \& Hedeen, 2005, p. 408), many organizations who refuse to comply with institutional norms, continuing their search for alternative goals, have not survived. This reality appears to have spurred other strategies beyond the traditional outsider-protestor model of social movement activism.

The insider situation questions the stringent boundaries drawn in social movement and public policy literature between social movements and the state (Banaszak, 2005). 
Insider status, however, is limited in its usefulness to answer the question at hand. The notion of an individual infiltrating the ranks of the institution is different than a strategy for an entire SMO to become institutionalized or co-opted early in the organization's life. The present case study, however, introduces a new strategic way to develop alongside a more powerful institution. Results, presented in the subsequent section, suggest that RJL developed by becoming embedded into the system early in its organization life. With this more specific focus of embedding an entire organization in the system, the literature rarely refers to the challenging movement as the agent in the process of co-optation. There are a few parallel exceptions that may assist in shedding light on this question.

The best example comes from the work of Lounsbury and colleagues' research on the environmental recycling movement (Lounsbury, 2001, 2005; Lounsbury et al., 2003). In this example, activists began working against the waste industry by organizing independent drop off centers run by local non-profit groups. This approach was unsuccessful. A dependable infrastructure did not develop until activists entered conventional policy channels and created relationships with the inside agencies and "retheorized" recycling programs as for-profit services that worked alongside established waste management programs (Schneiberg \& Lounsbury, 2008, p. 655). Their work led to changing the discourse and cultural beliefs about recycled material as a commodity and transformed practices on a larger scale (see Morrill, 2006 for the example of the alternative dispute resolution movement).

Though evidence of organizations working within the institution as a strategic move does exist, it is not a thoroughly examined area. Schnieberg and Lounsbury (2008) 
advocate for more thorough academic investigation conducted in this area. They promote furthering knowledge on how movements:

emerge from and exploit contradictions or multiple logics within fields to mobilize support, forge new paths or produce change...movements can emerge and operate within established channels and power structures, drawing on existing institutions and taken-for-granted understandings to theorize, articulate and combine new projects or practices with prevailing models and arrangements. ( $\mathrm{p}$. 650, p. 654)

Further understanding the possibilities, benefits, and limitations of deliberate institutionalization or co-optation has the potential to advance the connections between institutional change and collective action dynamics. 


\section{CHAPTER III}

\section{METHODOLOGY}

The social movements and organizations literatures are interested in the factors that influence the development and survival of a particular organization. This case study seeks to advance such knowledge, while attempting to contribute to an underdeveloped area of the research: the nascent stages of organizational life. The aim here is not to generalize results; the hope is to use the results to theorize about early SMO development and provide helpful information and considerations for emerging SMOs. Though it is not possible to know the long-term trajectory of the organization, this technique allows a glimpse into the organization's growth, while it is still emerging. Conversely, much of the work done on the survival of SMOs contains a selection bias, because they often choose to look at organizations after they have already succeeded or dissipated. Such studies involve retrospective research, rather than looking at the complex factors of an organization's development in the early stages of the process.

This case study employs a grounded theory approach to explore the trajectory of the Restorative Justice Louisville organization. Qualitative methodology is commonly employed in organizational research (Wood, 2012). More specifically, grounded theory is routinely used when gathering data on locally based organizations (Locke, 2001; Martin \& Turner, 1986). Referring to grounded theory, Locke points out, "after all, its genesis, in no small part, lay in studies of professional work carried out in complex organizational settings" (2001, p. 95). Moreover, recent research seeks to analyze 
organizations through a symbolic interactionist point of view, recognizing SMOs as more than mere resources to a movement, but as places of interaction and decision-making (Clemens \& Minkoff, 2004). This shift in SMO research fits well with the symbolic interactionist roots of grounded theory (Charmaz, 2006). Finally, grounded theory is a suitable option for social movement research in particular, because it is a method that helps bridge the divide between theory and practice (Locke, 2001). This is important for social movement literature, as the literature should be accessible to movement participants (Bevington \& Dixon, 2005).

Louisville is a valuable location for this investigation for two reasons. First, the debate continues around how restorative justice organizations should integrate and relate with the traditional juvenile justice system. RJL won favor from key supporters and became established from within the justice system very quickly. RJL's relatively swift decision and implementation in comparison to other organizations provides a rich setting to gain new insights about SMO growth and to explore the survival benefits and challenges corresponding to this developmental path. Second, participating myself in RJL, I had access to the activist community. Prior to beginning research, I was in contact with the executive director, which created a level of trust that made the request to pursue the organization as a research site a natural proposal.

I conducted semi-structured interviews with RJL's task force members and board members. Interviews lead to greater depth of understanding in comparison to other techniques (Gillham, 2003). Interviews also allow for better engagement of the complexities occurring in a specific environment (Brenner, M., Brown, J., \& Canter, 
1985). These advantages are of utmost importance in order to discern the complexities involved in RJL's implementation process.

I received approval from the University's Institutional Review Board prior to contacting members of the organization. I gained access to the members of RJL through the executive director. She sent out an email telling the board members and the task force members about the study in hopes of affording my request legitimacy and attention. I followed up her announcement with individual emails to each member. I went through the restorative justice facilitation training within the last year, and the director disclosed this information in her initial email. Though it is impossible to know for sure the impact of my current participation in the organization on the interviewees, it did not appear to dissuade participants from freely speaking about their experience with the organization. The majority did not remember my role in the organization. The few that did acknowledge my participation in the program seemed to be encouraged to speak in more detail and with greater excitement about the history and trajectory of the organization.

I completed seventeen interviews. Nine of the seventeen were task force members, six were board members, and two were members of both boards. The interview questions were guided by a preliminary review of the social movements and organizations literatures, and included questions about the participant's involvement in RJL and the organizational development in terms of structure, networks, strategy, and resource mobilization (see Appendix A). The average length of interviews was 43 minutes, ranging from the longest lasting 81 minutes and the shortest lasting 25 minutes.

When meeting with the participants, the voluntary nature of their participation was stressed and each participant signed a consent form. To protect their confidentiality, 
in the following analysis I do not use their names or identify them based on occupational titles that may reveal their identity. I did, however, designate whether they are board or task force members, as well as whether they are system or community players. In the subsequent results section, there may be a few cases where the identity of a member is clear to a longstanding member of the organization, due to the notoriety of the story, but to the extent of my ability, I protected the identities of all participants.

The interviews were digitally recorded and transcribed. The transcribed interviews were coded and analyzed according to grounded theory techniques (Charmaz, 2006; LaRossa, 2005). I began line-by-line coding as I continued collecting data, in order to focus the questions and information during the remaining interviews (Charmaz, 2006). After the interviews were initially coded, they were compared to one another in an attempt to begin conceptualizing and synthesizing larger sections of data. This is referred to as focus coding where the most significant codes from the first step are pursued. Finally, a version of axial coding was utilized to begin analyzing one category at a time and developing subcategories within each category (Charmaz, 2006; LaRossa, 2005). According to Charmaz, axial coding represents the step where the fragmented data from the line-by-line coding are reassembled into a cohesive whole. This is where I began to form the theoretical connections between the categories that I developed during initial coding. 


\section{CHAPTER IV}

\section{ANALYSIS}

\section{The Emergence of Restorative Justice Louisville}

The SMO in this case study was not inherited from a group of experienced specialists in restorative justice practices. It grew out of conversations focusing on larger questions about ways to make Louisville a more peaceful and just place. These conversations included people from the Louisville Bar Association (LBA) and overlapped with the committee that developed the Compassionate City Campaign. Throughout discussions and meetings between interested members in the city, the concept of restorative justice practices surfaced as one way to promote their compassionate mission.

One particular story surfaced in the interviews as a turning point to mobilize people around the idea of implementing a restorative justice program. A prominent member of the court system heard about restorative justice at an international conference. Upon returning to Louisville, she attempted the process informally in the courtroom. This experience solidified for her and others who heard the story that this was a possible alternative for dealing with conflicts between people. Her story led to subsequent conversations about the possibility of implementing this practice in Louisville.

Eventually the persons mentioned above and a few other inspired players came together and shared their idea to start a pilot project with the Disproportionate Minority 
Confinement Initiative. This committee is staffed by the Jefferson County Crime Commission, which consists of many key criminal and juvenile justice system players. With the merging of people from these different groups, they were able to create an initial advisory board to launch the organization that is now known as Restorative Justice Louisville (RJL).

The advisory board chose a willing leader who became the executive director to spearhead the pilot project. The members worked with the juvenile court system to get certain cases sent outside the court to RJL. If the case is completed successfully, the charges are expunged from the youth's record. If the process is not completed, the case is sent back to court (see Appendix B for a complete diagram of the process). The pilot project started in 2011 and as of March 2014, they have successfully completed 60 cases, are monitoring 12 cases, and are in the process of scheduling 8 new conferences. This brief introduction opens up a lot of unanswered questions about this organization's ability to develop with so few roadblocks, receiving more assistance from the juvenile justice system than opposition. In order to gain insight into the development process, the following pages share the story of this organization by examining the most significant factors that emerged during the interviews.

\section{Structure of the Organization}

As was made clear in the literature review, a significant aspect in organizational literature examines how the structure of a SMO impacts its development and potential for survival. Due to this fact, it is imperative to begin a conversation focused on questions surrounding development, by exploring how the early members decided to structure their SMO. This 
includes the leadership arrangement, the level of formality, and the decision-making procedures. The section concludes by providing a typology of players involved in the organization.

The members of RJL created a binary leadership structure, composed of the task force (once referred to as the initial advisory board) and the working board. In response to the people they gathered around their cause, they chose to populate the task force with players that were predominately a part of the juvenile justice system in some capacity. The main role of this group is to help with the logistical and legal decisions, along with assisting in the implementation of the program. The working board began with a few of the original advisory members and eventually invited largely community members from different businesses and organizations around the city, a few holding high profile positions. This board was strategically created to connect with people who would be able to fundraise and offer connections with potential funders.

Based on typologies from the SMO literature (Minkoff, 1993, 1999; Staggenborg, 1988), RJL possesses aspects of both informality and formality, but is set on a trajectory favoring formalization. The presence of formal structure is indicated by their 501c3 status, which precipitated the creation of bylaws, a mission statement, and a strategic plan. There was not unanimity among interviewees about whether the program should receive more public or private funding. There were many participants, however, who favored securing the organization to city or even state budgets, which signifies a movement towards a formal structure. The formal structure of the court system and the decision to create a task force with criminal and juvenile justice system players also encourages a high level of formality. 
The existence of an executive director predicts formality; although, the position has not been funded consistently and remains a volunteer position, which generally suggests informality. The director is the only full time employee and attends to the majority of day-to-day management and administrative duties of the SMO. The director's duties include overseeing the cases that get referred from the court, assigning facilitators to the cases, completing paperwork relevant to the case, and sending the information back to court after completion. The director is also responsible for applying for grant money, speaking to donors, and working with the board to raise resources as well. She directs promotional and marketing tasks, leads community meetings to promote the organization, and is the main communicator with key court and system personal. She is also a part of the leadership team, attending and often leading discussions with both boards. She recruits new participants, manages the interns, trains the facilitators, facilitates some cases herself, and is the main support person for the facilitators.

The facilitators are also volunteers. There are 42 trained facilitators. Facilitators' participation level greatly varies, with some trained volunteers not yet participating in a conference and the active volunteer receiving a steady caseload. This range depends on their availability and experience. The only other staff consists of interns from the University of Louisville. These volunteers work with the executive director in the office, managing paperwork and databases, monitoring cases, communicating with facilitators, and facilitating cases themselves. They also participate in the developmental aspects of the organization, attending and participating in meetings. Though the "volunteer" status 
implies informality, the organization is seeking funding for the director and hopes to someday pay the facilitators a small fee for their services.

In terms of decision-making, the majority of participants described RJL as a collaborative group, noting everyone was granted a voice and space to discuss their opinions and ideas. Only one exception to this trend surfaced. A member in the sample expressed deep frustration with the task force, perceiving a stratification of importance among the members based on occupational position. When asked if decision-making was collaborative, this task force member responded with the following statement.

I think they have an intellectual arrogance. 'I'm an attorney. I'm a politician. I rub shoulders with the mayor. And you sir, are a [profession removed for confidentiality reasons]. Oh ok.' They talk about themselves and they really don't ask for our view. And I think they probably know what our view is. We're a necessary evil they have to have. I'm not stupid, you can see how people feel.

Apart from this view, the participants in the sample report that the boards were places of collaboration and open dialogue.

One of the most important findings of this section is the influence the type of people who populated the leadership positions had on the structure of the organization. For instance, their decision to create a task force to oversee the logistics of the organization provided those in the juvenile justice system a level of influence from the very beginning. In a similar manner, the movement towards early formalization is influenced by the member's level of expertise and the number of professionals involved. Decisions concerning the structure of their SMO contributed to their success in establishing a program and these decisions were related to the type of people accessed by the original networks. 
Typology of RJL board members. As a whole, the members comprising both boards are professionals, largely from the justice system, business sector, and a few from academia. The majority of members are middle to late age, with only a few members younger than forty. The members of the two boards fit into two categories, largely based upon their professional position. There were those that were considered "system players" and those that were considered "community members." These are ideal types that do not define all players, but these categories assist in describing the members of the Restorative Justice Louisville leadership team.

System players. These individuals work in the criminal or juvenile justice system in some capacity: judge, attorney, court designated worker, crime commission member, etc. Both system and non-system players used this term. It was often a term used to differentiate these players from other RJL actors. Here is one example from a system player: "I knew all of the system people. I knew some of the community people, but I also met some new folks that were community folks that I hadn't had direct contact with." Another example comes from an interviewee who participated in both boards, “There's two groups - the advisory group filled with system players — court designated workers, judges. But then there's this other group that is more outside people I'd say." In this example, outside people are equivalent to community players.

Community players. These participants are not part of the justice system directly and predominately served on the working board, and in a few exceptions were members of the task force. Often these actors would clearly differentiate themselves as non-system 
players. At times this differentiation was said in a matter of fact tone, merely as a explanation; other times it was said to intentionally create distance between them, making sure to mention they were not "system" people. In response to a question about whether they ever go to someone outside of the restorative justice organization for assistance, a system player said, “To this point, I really haven't. I tend to be more on the system side. Certainly interact with all of the community players and have developed relationships with them, but still... The trouble shooting demand usually tends to be more on the system side than the community side." When referring to the decision about what offenses to include, a community member commented, "it wasn't something I had a lot of input in, I'm not a system player." Both of these comments not only create a clear distinction between different roles, but they also suggest that system players were given certain responsibilities and input not afforded the community player.

Overlapping roles. There were a few participants that had their foot in each group. For instance, one attorney did not work in the criminal system, but as a lawyer, came into contact with many of the system players. He described it like this, "I think me being motivated to get involved and help and being of the system, but not of the system was helpful for us getting it started." Another community member described herself as an activist who was previously "anti-system," but her current political position brings her in contact and collaboration with players in the system world (outside of her work in RJL), giving her a foot in both worlds. The interviews revealed that these individuals with overlapping roles were central to connecting the two separate player groups. This was evidenced by the numerous times these players' names surfaced in the interviews. 


\section{Social Networks Leading to the "Right" People}

This SMO is not a community-led initiative challenging the practices of an institutionalized organization, namely the justice system, from the outside. Instead, this group mobilized players from the community and from inside the court walls to develop an alternative to the traditional system. They achieved this goal not by convincing city or state legislatures or amending policy, but they convinced and collaborated with the players within the court itself to begin practicing something new and contrary to traditional practices. It is clear that they have been able to conduct restorative justice conferences with the assistance of people who were in positions to support the change in their day-to-day responsibilities. Arising out of the literature and from the mouths of those involved in this sample comes the question: how did they mobilize people, in this case people of prominent positions, to collectively work together? The answer to this question emerged during the interviews: the utilization of networks. The words from one of the members best introduce this theme: "If it wasn't for that collaboration and that network, I think it never would have happened here locally."

The early founders were well-connected people. These well-connected persons were not the ones who had the capacity to implement the program within the system, but they knew the people who could (occasionally through several layers of connections). Their professional positions led them to networks that were largely compiled of system players, several of whom would eventually became task force members themselves. The SMO literature reveals that networks are key resources and strategies for mobilizing people (Diani \& McAdam, 2003; Gerlach \& Hine, 1970; Kitts, 2000; Wang \& Soule, 
2012). The significance of RJL's networks, however, was not necessarily the number of people they mobilized, but that they led to the "right" people.

Participants used terms such as "right," "correct," or "necessary" to refer to the people they were able to organize, in every instance the person they were indicating worked directly in the juvenile justice system. An interviewee explained this situation with the following statements.

We began to meet on a regular basis and got some pretty heavy duty players involved and willing to participate and go along with it. All the right people were at the table and one thing led to another and low and behold we formed and got the ball rolling...I think we did pretty well at doing what we needed to do when we needed to do it. Finding the right people to help us do it.

These "right" people were of specific assistance in implementing this new approach in the court system because many of them were the ones in juvenile court everyday. A system player explained, "I think a lot of the people needed to make something like RJ work, are already involved in juvenile court, at least aware of how it works. And if they're not here every day, they're here often enough." These people were not the legislatures or political figures with noteworthy levels of power, but were able to change the system by incorporating RJL into their work place. As one participant explained, "It's a great program, but it's because the people who started it chose the right people to stay in it." This quote supports the theme that continued to emerge in the analysis: the people who began the organization knew the people to incorporate to get to their goal. For instance, the status of several people on the committee provided legitimacy and confidence that was fundamental to sway the county attorney's office, the public defender's office, and eventually even acquired the support from the mayor. The 
endorsement from high status people assisted in creating legitimacy for the organization, which has the potential of leading to additional networks.

As the task force grew, the organization itself became amassed with the people who held influence to begin altering the practices employed in the juvenile justice courtroom. Though there were multiple new connections made throughout the time to get this going, many of these networks were previously created networks that were now being co-opted to transmit a new message, which allowed RJL to establish itself and develop among the court personnel (Edwards \& McCarthy, 2004b). For example, a member said, "They were networks that were already bubbling over, relationships that had already been built, and this was just us working on something that we had never worked on before." A task member said she knew the executive director from when they worked in the same agency years ago. She revealed that overlapping job positions were not uncommon in their profession.

I'd had a bit of previous contact with her [the director]... a lot of the big cabinets people go back and forth in that sense. A lot of people start out with Child Protection Services and move over to Department of Juvenile Justice. So it's not that uncommon for DJJ folks to have that experience, quite a few people do actually.

As the above quotes suggests, some of the people knew each other from prior employment. Others mentioned knowing fellow participants from previous boards or committees they served on together.

The benefit of the networks did not end with the players in the system, but also reached out into the community, albeit to a lesser degree. Many of the community relationships were also reliant on previous relationships, both personal and professional. As one board member recounted, 
We carpooled with our kids to get them to school. He and his wife are Jewish and he has some connections to family foundations. I wrote him a letter two or three weeks ago asking for his help. Somehow he got my email address and wrote back that I can't do it with this foundation, but I can get a $\$ 1000$ from this other foundation for you. Oh by the way, here's what our kids are doing. It was a really nice exchange.

Certain community members were able to use their professional and personal connections to lead to corporate players, foundations, or other sources of financial support.

These findings do not mean however, that everyone in the system and in vital political positions supports or is even aware of RJL. Though these networks are composed of supportive members from the justice system and beyond the system who greatly assisted in the development of RJL, they still need subsequent assistance from higher status judicial leaders and more community involvement. Members believe that as the organization expands, further progress is needed to publicize their cause.

The group of people who began the RJL conversations led to networks of a certain type of person: established professionals with connections, resources, and a particular set of expertise. This theme reinforces theoretical claims about networks as principle tools used by SMOs and points more specifically to the importance of the status within a particular network (Gamson, 1990; Lindsay, 2008; McCarthy \& Zald, 1977; Tarrow, 1998; Tilly, 2004). The following sections begin to reveal the relationship between the networks of the original founders and their strategies.

\section{Strategies Used by the Organization}

In some situations, the mere connection with key players may assist with legitimacy and opening doors, but knowing important people does not guarantee support and success. Those players and their expansive networks must believe in the cause and 
be convinced of the mission, or at the very least, unopposed to the potential. This is where the strategy of an organization appears to be an important addition to the SMO literature. Collective action groups are faced with the task of deciphering the most effective ways to position the organization, frame their position, and tell their story. This organization is no exception. The examples that follow show how the leaders of RJL worked as "agents actively engaged in the production and maintenance of meaning for constituents, antagonists, and bystanders or observers" to promote collective action through tactics and frames (Benford \& Snow, 2000, p. 614).

According to one of the participants, several years ago a member of a local mediation group attempted to implement a form of restorative justice in Louisville, but to no avail. They did not have the correct influence, and the connections they did have were not prepared for it at the time. The interviewee said, "We had people in the right positions, but they weren't persuaded." Even when connections are present, strategic methods are employed to encourage support (Gamson, 1990; Minkoff, 1993). Such findings lead to the question: what has RJL done to develop an organization with minimal to no pushback, and garner more support than the founders could have imagined?

As the prior section spelled out, throughout the past two years the founders and various supporters were busy exercising their networks to gain access to decision makers and build the task force and working board. The subsequent pages address the strategies and frames this collective group chose and implemented to mobilize people and gain their support.

Mobilization through cooperation. Restorative Justice Louisville is an 
organization that utilizes agreement and compliance strategies rather than opposition to create legitimacy and open doors into a particular space. In this case, that space is the court system. This section provides an account of their agreement strategy by looking at the specific tactics and frames employed to reach their goals. These include their decision to embed the program in the juvenile justice system, distance themselves from more combative groups, and utilize non-threatening and collaboration frames.

A productive way to produce legitimacy in the eyes of the state, corporate partners, and the community is to "abide by institutional norms" (Walker \& McCarthy, 2010, p. 318). This is precisely the path RJL chose. Walker and McCarthy go on to say that an organization's legitimacy is necessary for survival and is not only reflected by the people who support the organization, but "is reflected in their degree of embeddedness in their institutional environments" (2010, p. 319). As a program, RJL followed the "institutional norms" of the justice system in order to establish their program. This reflection from a key system player demonstrates the presence of strategic embeddedness:

I think the way an organization positions itself is critical, particularly in a criminal justice environment. If they were seen as just driving an agenda regardless of how the system operates, not be willing to operate within the existing system, or being critical of the system. It could kill the program.

This sentiment was echoed by many other interviews. The players decided not to create waves, but to operate within the system. They invited people in the juvenile justice system to the table and worked within the norms and language of this sector to achieve their objective.

One participant said their tactic to embed within the institution was to remain "non-threatening" to the justice system. He went on to say, "I think you have to honor, 
you don't try to roll over people." Another respondent said, "I think a lot of people who desire to make changes tend to vilify people in the system... I think we've been able to make the changes because we haven't tried to cram anything down." They did not utilize sits-ins or protests or make demands until the other side negotiated or recoiled. Instead, they initiated conversations, brought system players into the leadership committees, and incrementally sidled into the court to implement the organization.

An indicator of their desire to remain closely aligned with the system was the method of differentiating themselves from another organization in the city that works for change, but often through more oppositional tactics. Several years ago, this oppositional group took part in advocating for restorative justice practices, primarily in the schools, but they used methods that differed greatly from RJL's tactics. For example, one member said, "They have sometimes aggressive or antagonistic approach, particularly when dealing with system." Others referred to them as intimidating, rude, and a bully. Multiple participants mentioned this group and their direct tactics, indicating that their methods did not work within the norms of the institution they were attempting to change. The participants distancing and differentiating their organization from this group is suggestive of their own strategy to remain closely aligned with the institution, rather than as a challenger to the institution.

When I asked if it was an intentional strategy to come alongside the system instead of opposing it, a task force member responded by saying:

I think, yeah. In order to get the pilot started - engaging and having the support from all the players of the system-you got to do it. So I think in that regard it's laid a firm foundation. Its not an us vs. them, its more of our program. 
Along with showing the intentionality of their method, this comment depicts the way they frame themselves as collaborators rather than opponents. Another activist said, "You don't position it as an either/or, you position it as a both/and." Both of these sentiments capture the larger frame of cooperation.

Of course, not all members were on the same page with every organizational decision. The majority of interviewees spoke with favor about the strategy to head further into the system, rather than to remain outside and separate. Several people, however, explicitly mentioned their disagreement with the choice to embed the program so deeply within the system, and a few others hinted at it without overtly providing their stance. In general, these members believed the program should have more of a community focus and presence. This is the most transparent comment made on the subject:

I have very strong opinions and I've shared them with the board. I definitely believe that we have to remain as a community-based entity, not something that falls under government. In fact, I feel uncomfortable that we have a government phone number, our 574 extension, just because I feel like, you know, most people that I know are not comfortable calling governmental entities, just for whatever reason...But we should remain outside of the system, and not necessarily because we are fighting one another in this antagonistic relationship, but because the community, to me, is what's most important. And the community needs to see us as accessible, as friendly, as approachable, because they for the most part have not had the best relationships with and interactions with the system.

Another member agreed with this sentiment:

For me it came out of the system more than it came out of the community... I don't think of this as a social justice community-based organization. It's just a different model. I think there are pros and cons of both models. When I joined the task force...part of what [name removed for confidentiality] and I talked about, there is a difference between starting a program and then inviting a diverse group in, from starting with a diverse group in the beginning. Invite me to the table in the beginning I'm going to approach the program differently if you bring me in when you've set everything up...Happily, the system players helped make it happen. And in this community, that may have been a necessity. 
Though there were few blatant statements like the ones above expressing disagreement with the direction of the organization, several comments about leadership and membership reflect an analogous viewpoint. Most of these individuals saw the benefit of inviting high status people to the table, but were concerned they were loosing an opportunity to recruit people who were more representative of those they were seeking to serve. This is one member's reflection:

It was not ill intentioned that it happened that way, but when you looked around the room it was all east end people trying saying what should happen in another area of town and we don't have any representation on here... I think I brought that up a couple of times, that we needed to pay attention to diversity and there was a tension about do you want people who can make big donations to keep this going or...

These participants believe that in order to create a program that is truly aligned with the needs of the community, there must be more people in leadership positions that are from and representative of those neighborhoods. This critique included the lack of racial and neighborhood diversity. Several comments focused on the fact that members "looked just like me on the board," referring to oneself as a middle-class white professional. The following quote provides a direct example of the race component:

The way RJ organization developed that model, it was the people propelling so much of this were white folks. It was the type of board that they were seeking were people to shake trees and raise money. They weren't necessarily people that were engaged with the group. That's not necessarily a bad thing. They brought people in committed to the idea. But is this coming from the community or a group of people? I think it came from a group of people.

Often times the comments expressing hints of tension surfaced when members were asked about the function of networking in the development. For example, one interviewee responded by saying, "I think that [the benefit of networks] is particularly 
true for the system network." Another member focused her response on the "weakness" of the connections they chose:

I think it's great to have all of those people, but it's also a weakness. We are so connected that we don't look beyond those connections-whether it's the communities we serve and having more people who are diverse on the board.

A working board member echoed this view in the next quote:

We have to move beyond these networks, we have to get community folks on board, like we need to have folks on the board who have gone through the process, who can speak from their own experience, so it's not us theorizing. You have me, the only person actually living in the neighborhoods we're serving, and then we have everyone else who lives east, like, am I the only person who sees this disconnect?

These statements point to the literature on the strength of ties, affirming the finding that strong ties do not allow for networks to breach familiar circles (Edwards \& McCarthy, 2004a; Ganz, 2000; Granoventter, 1973; Strang \& Soule, 1998). In this example, it may not have constrained development, but some of the participants perceived it as a weakness in mobilizing a diverse support base.

It appears that the substantial presence of system players transcended the opinions of those that were critical or skeptical about the organization's direction. At this juncture it is necessary to point out that when asked about opposition or disagreement in decisionmaking, these same participants who mentioned dismay at the level of system embeddedness also spoke positively about RJL's collaboration and did not suggest that there were deep conflicts among members. Multiple participants also admitted that they communicated their hesitation to their prospective boards, thus clarifying that the decision to move further into the system to establish the organization may not have been filled with tense, divergent conversations. But opposing viewpoints did surface in regards to these important organizational questions. Opposition to the decisions was present, yet 
their strategy to head further towards system partnerships remained the course. The presence of divergent voices shows that they made a decision; their actions were not merely subjected to structural or political constraints.

Bridge between opposing viewpoints. Along with presenting their mission as collaborating with the system, they also framed the philosophy of the organization as a bridge between competing ideologies. Many times, the history of criminal justice reform, and for that matter the history of social movement literature, is a story of fierce opposition. Competing ideologies have been both political and judicial in nature. The court system itself is based on an adversarial process between prosecution and defense. The advocates of this organization, however, claim that their program provides advantages for both sides:

And that's the big thing about this, we can hit it from all angles. People who are more liberal will like it because it's about human needs. But people are more conservative will like it because it's victim-centered too. You're looking out for the victim, there is nothing soft about it. The agreed upon accountability tend to be more than judge imposed sentences. The difference is if you have some say in your accountability and own it you can move through it and let go of it.

A task force member agreed by saying, "It's hard not to want to support...It sort of touches all the key parts from a prosecutor and defense perspective, from a judicial perspective." They perceive and promote their organization as a philosophy that can be embraced by people on both sides of the political or judicial aisle.

In order to use this frame to its fullest, they utilized one-on-one meetings. This approach allowed them to carefully curate their story to resonate with a particular person based on his/her political or ideological perspectives. One of the early founders argued that in order to spread the message to multiple individuals with competing ideologies, one 
must "know your audience." Knowing one's audience prepares the activist to sell the concept to people from either side of the political or judicial divide.

Providing the system a level of control. RJL's collaboration with the court did not stop with the compliance to the institutional norms; they also provided the system a level of control over the program's development. This is exemplified by examining the SMO's decision as to which offenses to include in the restorative justice program. The members of the board did not approach the prosecuting attorney's office with a list of suitable offenses and ask for their cooperation. Nor did they stage a mass protest until they were given access to the court. They did not lobby their local politicians, encouraging a high status official to use a top down approach to demand change. They gave a blank piece of paper to the prosecuting attorney and asked them which offenses they thought were appropriate. A prosecuting attorney explained it this way: "I would also say I think our office retained almost veto power...I don't know how much collaboration there was about which offenses would be considered. I think maybe to get the county attorney's office on board, people were ok with that."

This is not the only example of the organization providing people in the juvenile court system a level of influence and control. In fact, the program logistics were strongly impacted by the system's needs and requests. One of the system members mentioned, “They've [RJL] been real flexible in trying to meet our needs within the court system." They sought the support and collaboration of those who have the power to make the changes in their daily lives, by welcoming their input about the organization's decisions and direction. 
A service to the overwhelmed courts. RJL also framed their mission as a service to the court. This was used as a tool for gaining support from those in the system, who were the most familiar with the needs of the juvenile justice system. In consonance with the literature, this is productive because frames should resonate with prior messages (Babb, 1996; Snow and Benford, 1988). The message from the juvenile justice system is that they are overworked, under funded, and in need of different approaches. As one participant proclaimed, "the whole court system is overwhelmed as it is." This message extends beyond the local level as the federal criminal justice system is experiencing similar issues, which increases the resonance of the frame. RJL frames their program as a way to decrease the cases on the docket, lessen the load of the lawyers, reduce risk for judges, and save money for the larger justice system.

The following excerpts from the interviews exemplify these points. During an interview, a system player admitted the reason he would buy in to the organization, "I'm always willing to try something different, because of the volume of cases and how young these kids are." A community member claimed, "the judges appreciate that [RJL's service], because they're getting bombarded." A system member confirmed the above declaration with this statement, "It saves the prosecutor time that morning. It saves the defense attorney time. It saves me time, its one less case on my docket." These comments from the interviews reveal that the service to the courts frame is resonating with system players.

One of the prominent board members explained how he describes it to those in the system: 
We've positioned it as - to judges — as safe. They're overworked and I say look, if you got the victim there, the facilitator, the offender, sometimes police there, and they come up with an agreement and its presented to you there is little to no risk to you as a judge to accept it... So with this, when you talk to judges about itlook we're trying to lighten your docket.

This final quote sums up several of the claims, coming from an a system player in the juvenile court:

I'm very encouraged by it. Just from a numbers perspective its good because, it takes--I think they're up to 200 cases. That's 200 cases that didn't come to court and we didn't have to use resources, which is good... There are a lot of cases, there are dwindling resources, whether the prosecutors or defenders office or social workers. We have so many cases in Jefferson County. If there is another way to handle them, I think people are willing to try it, to see if it's going to work. I hate to say it, but a more cost effective way.

It is clear from the above statements that presenting RJL as a service is a resonant frame, as well as a useful tactic for gaining the approval from those most aware of the needs of the juvenile justice system.

Secondary frames. Along with the primary strategies that surfaced, there were a few others that routinely emerged as a way to frame and position the organization. Several times they said they utilized emotional and powerful stories. These were generally anecdotal stories from RJL's early experience and successful programs from other sites in the U.S. and abroad. Along with anecdotal support, they also relied heavily on past research to legitimize the claims that this is a reputable, effective way to deal with youth offending.

Several interviewers also contended that restorative justice practices provide a holistic solution to juvenile offending, getting at the roots of crime and building the community. A community member said, "I think that we too much don't address the root 
of issues, whether it's with alcoholism or why someone would be committing a crime.

It's [RJL] more of the holistic approach." The supporters also said that restorative

conferences provide the offender, victim, and families more meaningful experiences than

in court. For example, one member said restorative justice,

May be more meaningful than coming to court and sitting around for a couple of hours and not being very involved in the process... Sometimes I think, especially victims, feel like they've had more meaningful input into the process when there is a group conference. Instead of just showing up to court and the prosecutor saying these are the options, here's what's going to happen and they sort of just have to accept it and they might not even like it, but there are certain constraints on what can and can't be done. Where as with RJ, if they have a little bit of input it makes everyone feel better.

Comparable views came from community members, judges, and a prosecuting attorney.

While describing the most salient themes emerging from the interviews, this chapter confirms central tenets from social movement and organizational theory. However, a few novel themes emerged not addressed in the extant social movement organization literature. These findings will be developed in the following chapter. 


\section{CHAPTER V}

\section{DISCUSSION}

The findings in this case study illuminate past theoretical themes in social movement and organizational research regarding the importance of structure, networks, and strategy to a SMO's development. In this search to understand RJL's formation, however, an interesting concept emerged. The degree of RJL's collaboration with the justice system, the institution they were working to transform, resembles what I call "preemptive cooptation." Rather than remaining separate from the system and changing it from outside the court walls, they embedded their organization within the juvenile justice system early in their development. They adapted the language and structure of the criminal justice institution, they allowed the system's influence on their goals and practices, and they relied on system involvement more than community support (Coy \& Hedeen, 2005). The following chapter provides illustrations from the analysis to support this claim. Within this section, I show how RJL's choices during the first few years provided mechanisms for co-optation to occur and propose that the co-optation was motivated by the decisions of the organization itself. The final pages ask what this finding may mean for other social movement organizations.

The structure of the organization is the first mechanism where this process is recognizable. Early in the establishment of the organization, RJL provided system players a high level of participation in the decision-making structure. Within the 
overlapping networks at play in the development of RJL, there were people who had many system connections and who believed the system's involvement was critical to the program's growth. As one participant commented, it was important to get "heavy duty players involved and willing to participate and go along with it," referring to them as "the right people." Dealing with the problems that arose became the role of the system players, who were already a part of the justice system. A system player asserted, "the trouble shooting demand usually tends to be more on the system side than the community side." From initial development stages, the role of the system was seen as critical and given high importance in making decisions for the organization.

Incorporating system players into the organizational structure established RJL firmly inside the justice system, giving them access to the county attorney, judges, prosecutors and the whole of the crime commission. Embedding the organization in the juvenile justice system, which itself is a highly formal institution, also influenced the formality of RJL. For example, a board member remarked,

if we're trying to sell in Metro government, people just want stability, to know your structure, where you money is going...Some of the formal stuff we need to put together for grants, like if we're going to send something to Frankfort, they're going to want to know those things. Even something like an annual report...people want to see that, that's official, this is how we're handling our money. Those are the types of pieces that we really need to get on board with.

This relationship resembles Dimaggio and Powell's notion of coercive isomorphism (1983), defined by Coy and Hedeen as the "influential role of powerful exogenous institutions and resource providers, particularly the state, in fostering or imposing the reproduction of organizational patterns" $(2005$, p. 408). The board member's quote suggests that RJL participants were considering how their organization would appear in the eyes of the larger governing body, in this example, the state. They fashioned certain 
parts of their organization to coalesce with the governing institution's expectations. By choosing to embed their organization into the juvenile justice system, their organizational form was susceptible to its influence.

The strategies the initial founders chose were influenced by the kinds of people involved, thus motivating the organization to follow accepted institutional norms. According to the results of the study, it matters who the founders are and who they know. As one member said, "It's a great program, but it's because the people who started it chose the right people to stay in it." The founders of RJL and the members who populate the boards are the type of people most SMO's want on their side in order to access critical networks, potential resources, and expertise. Choosing to implement the organization through these networks and connections greatly impacted their ability to develop and may aid in the longevity of the organization, not only for the obvious reason that status and influence of supporters provided legitimacy and access, but also that the people involved greatly shaped the strategies of the organization and sent it deeper into institutional relationships and connections. This allowed the organization to develop from inside the juvenile justice court, providing it, at least for the time being, a measure of assurance and legitimacy. Their strategies, therefore, were in part effective because of the people that were on board. At the same time, the participants were there because the organization's strategy took them towards a certain type of supporter. The interchange between these two factors assisted them in developing inside the juvenile justice system.

Due to the relationship between strategies and networks, RJL's strategies largely complied with the rules of the justice system. Restating the viewpoint from a system player helps exemplify this point: 
I think the way an organization positions itself is critical, particularly in a criminal justice environment. If they were seen as just driving an agenda regardless of how the system operates, not be willing to operate within the existing system, or being critical of the system. It could kill the program.

RJL intentionally operated "within the existing system," choosing not to be critical of the program. They invited people in the juvenile justice system to the table and worked within the norms and language of this sector to achieve their objective. They admitted they wanted to appear "non-threatening." A respondent distanced RJL from organizations that "vilify people in the system," instead claiming, "we've been able to make the changes because we haven't tried to cram anything down." By explicitly commenting on another organization's "aggressive or antagonistic approaches," especially "when dealing with system," indicates that their own methods differ from this group.

An indicator of RJL's desire to collaborate with, rather than confront the system, was the organization's use of flexible framing. They worked diligently to meet the needs of people within the system on both the defense and prosecutorial sides, as well as meeting the requests of those with both conservative and liberal ideologies. By knowing the players involved, RJL would be able to craft an argument based upon their stance. To achieve this goal, they had one-on-one meetings to better highlight the parts of the frame that resonated with that particular person. They were actively searching for approval and acceptance from those inside the system.

The most compelling clue that RJL was a part of the process of their co-optation was the high level of control they provided the system from early on in the establishment. The most striking examples are the role they gave the county attorney's office to make the decision about which offenses to send to RJL. A system player made it clear that the 
prosecutor's office "retained almost veto power," over the direction of this decision. They also afforded the participating judges and court personnel a platform to provide ongoing guidance and evaluation of the program. For example, a task force member said RJL was "flexible in trying to meet our needs within the court system." This level of control and participation allowed the system investment and acceptance in the SMO's continued expansion and growth.

As the results section outlined, not all participants fully agreed with the direction of the organization. One of the common complaints was that RJL was not communitybased and was too dependent on system level constraints. For example, one interviewee said, "I have very strong opinions and I've shared them with the board. I definitely believe that we have to remain as a community-based entity, not something that falls under government." Another complaint was the lack of diversity, regarding neighborhood of residence, race, and profession of the members. Most of these individuals understood the benefit of pursuing system players, but admitted they thought they also needed to work hard to incorporate people from the neighborhoods RJL invested time and resources. One member reflected, "when you looked around the room it was all east end people trying saying what should happen in another area of town and we don't have any representation on here." Another member focused her response on the "weakness" of the connections they chose when she said, "we are so connected that we don't look beyond those connections - whether it's the communities we serve and having more people who are diverse on the board." A working board member reiterated this stance, "we have to move beyond these networks, we have to get community folks on board." The presence of divergent voices shows that they made a decision. Despite these 
opposing views, the strategy to work closely with the juvenile justice system exceeded alternative opinions.

Early on in the life of RJL, the leaders made decisions that set them on a trajectory heading towards a strong collaboration with the juvenile justice system. Although it is not possible to say that this was an initial, premeditated goal, the findings support the notion that intentional steps made by the members in RJL, rather than the challenged institution, determined the organization's route of action. In the account by Coy and Hedeen, they were struggling to determine whether co-optation was the original intention of the state or institution in their example. They point out, almost in jest, "Such comprehensive, integrated, and long-range grand plans are rare enough in policy circles; even rarer is their effective implementation" (2008, p. 410). While admitting this, however, they also acknowledged the reality that intentional decisions along the way led to co-optation. The results in this case study suggest a similar situation. The results cannot confirm whether the strategy to become co-opted was a long-range grand plan; however, it is evident that they did make deliberate decisions leading them to this strategy. Such a claim is supported by the following response to my question about whether it was an intentional strategy to come alongside the system instead of opposing it:

I think, yeah. In order to get the pilot started — engaging and having the support from all the players of the system-you got to do it. So I think in that regard it's laid a firm foundation. Its not an us vs. them, its more of our program. [emphasis added]

The participants in the study did not use the word "co-optation," but the decisions they made about the development of their SMO set them on this unique course. 
As discussed in the literature review, co-optation has not been referred to as a strategy utilized by movement organizations. The closest exceptions that relate to this topic come from the research focusing on the benefits of insider status (Banaszak, 2005; Gagne, 1996; Santoro \& McGuire, 1997) and works by Lounsbury and colleagues’ examining the environmental recycling movement (Lounsbury 2001, 2005; Lounsbury et al., 2003). But generally, theories of co-optation speak about the institution as the agent in this process (Coy \& Hedeen, 2005; Piven \& Cloward, 1977). The findings in this case study introduce a new possibility that the literature on movements has not yet considered. The results reveal the possibility of seeking preemptive co-optation as an early strategic move in order to gain legitimacy, resources, and access to the arena that the SMO is attempting to change. Though this case study barely scratches the surface of what this developmental process means, it affirms the assertion that there are a variety of ways for a SMO to develop (Clemens, 1993; Minkoff, 1993, 2002; Zald \& Ash, 1966). This case study introduces a new possibility.

The literature largely speaks of co-optation as a gradual process, one that can diminish movement goals, may result in the deterioration of the SMO, and should be avoided at all costs (Piven \& Cloward, 1977; Coy \& Hedeen, 2005). For the participants in the case study conducted here within, they saw steps toward co-optation as an option to realize their goals. Because my research was conducted so early on in organizational life, there is no way of knowing if this strategy of preemptive co-optation will prove effective for RJL's longevity or goal achievement. But at this point, it appears they were able to integrate quickly and effectively into the system. This raises an important question: Is this preemptive co-optation beneficial? For instance, by acting as the agents in the 
process of preemptive co-optation and allowing or even choosing such an outcome to occur, does this permit them to by-pass some of the pains that come when co-optation is unintentional or unsolicited? Are the foreseeable gains worth the anticipated negatives the literature warns about becoming too closely aligned with the system?

These questions speak to the irony referred to in the literature review. Formalization and institutionalization encourage the development and survival prospects of the organization (Andrews, 2001; Edwards, 1994; Edwards \& Marullo, 1995; Minkoff, 1993, 2002; Walker \& McCarthy, 2010), yet also increases the risk of co-optation (Coy \& Hedeen, 2005; Piven \& Cloward, 1977). The current case study may provide one way to deal with this paradox; it questions whether co-optation is only a negative result and simultaneously proposes its use as a strategic plan. The exceptions in the literature that suggest co-optation is not always a negative prospect (Lounsbury, 2001, 2005; Lounsbury et al., 2003) support the idea that there could be benefits of a SMO becoming a part of the system they are trying to change. These scholars advocate for more comprehensive investigation to advance knowledge on how "movements can emerge and operate within established channels and power structures, drawing on existing institutions and taken-for-granted understandings to theorize, articulate and combine new projects or practices with prevailing models and arrangements" (Schnieberg \& Lounsbury, 2008, p. 654). Clemens (1993) supports the idea that a progression towards "conservatism," in the Weberian sense, does not inevitably lead to an inability to create change. In her words, "social movements can be a source of institutional change even if they themselves undergo transformations of a more or less conservative nature" (1993, p. 759). Kriesberg 
(2003) recognizes the disadvantages of institutionalizing, but also acknowledges the potential beneficial outcomes of institutionalization and even co-optation.

An important final question is whether this model holds lessons for other social movement organizations. "Once one group has pioneered the use of an organizational model in a new arena, that model may then be adopted for use by other groups" (Clemens, 1993, p. 773). This claim from Clemens comes from her research on the women's movement, but can be applied here as we question how the findings in this case study can be functional for other social movements. Further case studies, comparison studies, and longitudinal research are necessary to begin answering such questions. For restorative justice organizations in particular, there is a need for studies questioning whether there are differences in community crime rates, satisfaction, and cohesiveness between organizations that stay embedded in the community compared to those who allow the system a high level of control. On the organizational front, there is a need for studies addressing differences in organizational effectiveness, longevity, and goal preservation based on various pathways of growth, including this new possibility of preemptive co-optation. In addition, due to potential detriments written about co-optation in the literature, continued movement research needs to better identify boundaries for when this strategy may be beneficial or appropriate. The first recommendation for determining if a SMO should pursue this strategy is whether they have elite allies. Connections with people within the institution the SMO is attempting to change should be present before pursing this strategy. The second recommendation is to consider the fortitude of an organization and its members to stay committed to their goals before heading deep within the institution they are attempting to change. 
This study also raises questions that cannot only be answered through research. Even with the improved knowledge about social movements that scholarship provides, ultimately social movement actors make decisions about how and why to develop their organization in a certain way. This research introduces a new method for encouraging change that may have replication prospects for other movements. However, those involved in the conversations need to carefully weigh the pros and cons and consider if their goals can be met through this method or if they need to stay more closely aligned to a community-based style.

For organizations that are open to system collaboration, the successful development of this organization in Louisville may be good news. For those programs that wish to remain outside the system, this research serves as a caution; the people, structure, and strategies an organization pursues in its early developmental phases can greatly impact the organization's trajectory. Though this case study does not claim to provide a clear pathway for activists or scholars, it does broach significant questions to consider when thinking about establishing and researching a social movement organization. 


\section{REFERENCES}

Abrams, L. S., Umbreit, M., \& Gordon, A. (2006). Young offenders speak about meeting their victims: Implications for future programs. Contemporary Justice Review, $9(3), 243-256$.

Andrews, K. T. (2001). Social movements and policy implementation: The Mississippi civil rights movement and the war on poverty, 1965-1971. American Sociological Review, 66(1), 71-95.

Andrews, K. T., \& Edwards, B. (2004). Advocacy organizations in the U.S. political process. Annual Review of Sociology, 30, 479-506.

Babb, S. (1996). A true American system of finance: Frame resonance in the U.S. labor movement, 1866 to 1886. American Sociological Review, 61, 1033-52.

Banaszak, L. A. (2005). Inside and outside the state: Movement insider status, tactics, and public policy achievements. In D. S. Meyer, V. Jenness, \& H. Ingram (Eds.), Routing the opposition: Social movements, public policy, and democracy (pp. 149-176). Minneapolis: University of Minnesota Press.

Bazemore, G. (2001). Young people, trouble, and crime: Restorative justice as a normative theory of informal social control and social support. Youth \& Society, 33(2), 199-226.

Bazemore, G., O’Brien, S. \& Carey, M. (2005). The synergy and substance of organizational and community change in the response to crime and conflict: The 
emergence and potential of restorative justice. Public Organization Review: A Global Journal, 5, 287-314.

Beckert, J. (1999). Agency, entrepreneurs, and institutional change. The role of strategic choice and institutionalized practices in organizations. Organization Studies, 20, $777-799$.

Benford, R. D. (1997). An insider's critique of the social movement framing perspective. Sociological Inquiry, 67(4), 409-430.

Benford, R. D., \& Snow, D. A. (2000). Framing processes and social movements: An overview and assessment. Annual Review of Sociology, 26(1), 611-639.

Bevington, D., \& Dixon, C. (2005). Movement-relevant theory: Rethinking social movement scholarship and activism. Social Movement Studies. 4(3), 185-208.

Blumer, H. (1969). Collective behavior. In A. M. Lee (Ed.), Principles of sociology (3rd Ed.) (p. 65-121). New York: Barnes and Noble Books.

Bolitho, J. (2012). Restorative justice: The ideals and realities of conferencing for young people. Critical Criminology, 20(1), 61-78.

Bonta, J., Wallace-Capretta, S., Rooney, J., \& McAnoy, K. (2002). An outcome evaluation of a restorative justice alternative to incarceration. Contemporary Justice Review, 5(4), 319-338.

Bradshaw, W., \& Roseborough, D. (2005). Restorative justice dialogue: The impact of mediation and conferencing on juvenile recidivism. Federal Probation, 69(2), 15-21.

Brenner, M., Brown, J., \& Canter, D. V. (1985). The Research interview, uses and approaches. London: Academic Press. 
Button, J. (1989). Blacks and social change. Princeton, NJ: Princeton University Press.

Calhoun, A., \& Pelech, W. (2010). Responding to young people responsible for harm: A comparative study of restorative and conventional approaches. Contemporary Justice Review, 13(3), 287-306.

Caniglia, B. S., \& Carmin, J. (2005). Scholarship on social movement organizations: Classic views and emerging trends. Mobilization: An International Journal $10(2), 201-212$.

Charmaz, K. (2006). Constructing grounded theory: A practical guide through qualitative analysis. Los Angeles: Sage.

Choi, J. J., \& Gilbert, M. J. (2010). 'Joe everyday, people off the street': A qualitative study on mediators' roles and skills in victim-offender mediation. Contemporary Justice Review, 13(2), 207-227.

Choi, J. J., Green, D. L., \& Kapp, S. A. (2010). Victimization, victims' needs, and empowerment in victim offender mediation. International Review of Victimology, 17(3), 267-290.

Clemens, E. S. (1993). Organizational repertoires and institutional change: Women's groups and the transformation of U.S. politics, 1890-1920. American Journal of Sociology, 98, 755-798.

Clemens, E. S., \& Minkoff, D. C. (2004). Beyond the iron law: Rethinking the place of organizations in social movement research. In D. A. Snow, S. A. Soule \& H. Kriesi (Eds.), The blackwell companion to social movements (pp. 155-170). Malden, MA: Blackwell. 
Coy, P.G., \& Hedeen, T. (2005). A stage model of social movement co-optation: Community mediation in the United States. The Sociological Quarterly 46, 405435.

de Beus, K., \& Rodriguez, N. (2007). Restorative justice practice: An examination of program completion and recidivism. Journal of Criminal Justice, 35, 337-347.

Diani, M. \& McAdam, D. (2003). Social Movements and networks. New York: Oxford University Press.

DiMaggio, P. \& Powell, W. W. (1983). The iron cage revisited: Institutional isomorphism and collective rationality in organizational fields. American Sociological Review, 48(2), 147-160.

Edwards, B. (1994). Semi formal organizational structure among social movement organizations: An analysis of the U.S. peace movement. Nonprofit and Voluntary Sector Quarterly, 23, 309-33.

Edwards, B., \& Marullo, S. (1995). Organizational mortality in a declining social movement: The demise of peace movement organizations in the end of the cold war era. American Sociological Review, 60(6), 908-927.

Edwards, B., \& McCarthy, J. D. (2004a). Strategy matters: The contingent value of social capital in the survival of local social movement organizations. Social Forces, $83(2), 621-651$.

Edwards, B., \& McCarthy, J. D. (2004b). Resources and social movement mobilization. In D. A. Snow, S. A. Soule \& H. Kriesi (Eds.), The blackwell companion to social movements (pp. 116-152). Malden, MA: Blackwell. 
Evans, S. (1980). Personal politics: The roots of women's liberation in the civil rights movement and the new left. New York: Vintage.

Ferree, M. M., \& Hess, B. B. (1985). Controversy and coalition: The new feminist movement. Boston: Twayne Publishers.

Freeman, J. (1979). Resource mobilization and strategy: A model for analyzing social movement organization actions. In M. N. Zald \& J. D. McCarthy (Eds.), The dynamics of social movements (pp. 167-189). Cambridge, MA: Winthrop.

Gagne, P. (1996). Identity, strategy, and feminist politics: Clemency for battered women who kill. Social Problems, 43(1), 77-93.

Gal, T., \& Moyal, S. (2011). Juvenile victims in restorative justice. British Journal of Criminology, 51(6), 1014-1034.

Gamson, W. (1990). The strategy of social protest. Belmont: Wadswoth.

Gamson, W. (1995). Constructing social protest. In H. Johnston \& B. Klandermans (Eds.), Social movements and culture (pp. 85-106). Minneapolis: University of Minnesota Press.

Ganz, M. (2000). Resources and resourcefulness: Strategic capacity in the unionization of California agriculture, 1959-1966. American Journal of Sociology, 105(4), 100362.

Gerlach, L. P., \& Hine, V. H. (1970). People, power, change: Movements of social transformation. Indianapolis: Bobbs-Merrill.

Gillham, B. (2003). The research interview. New York: Continuum.

Granovetter, M. S. (1973). The strength of weak ties. American Journal of Sociology, 78, $1360-80$. 
Hannan, M. T., \& Freeman, J. (1989). Organizational ecology. Cambridge, MA: Harvard University Press.

Hwang, H. \& Powell, W. (2005). Institutions and entrepreneurship. In S. Alvarez, R. Agrawal, \& O. Sorenson (Eds.), Handbook of entrepreneurial research (pp. 179-210). New York: Springer.

Jasper, J. (2004). A strategic approach to collective action: Looking for agency in socialmovement choices. Mobilization, 9(1), 1-16.

Jenkins, J. C. (1977). Radical transformation of organizational goals. Administrative Science Quarterly, 22(4), 568-586.

Jenness, V. (2005). The social movement-state nexus: The structure and consequences of interpenetration. In: D. S. Meyer, V. Jenness, \& H. Ingram (Eds.), Routing the opposition: Social movements, public policy, and democracy (pp. 117-120). Minneapolis: University of Minnesota Press.

Johnstone, G., \& Van Ness, D. W. (2007). Handbook of restorative justice. Cullompton, Devon: Willan.

Johnstone, G. (2008). The agendas of the restorative justice movement. Sociology of crime, law and deviance, 11, 59-79.

Katzenstein, M. F. (1998). Faithful and fearless: Feminist protest inside the church and military. Princeton: Princeton University Press.

Kitts, J. A. (2000) Mobilizing in black boxes: Social networks and participation in social movement organizations. Mobilization: An International Journal, 5(2), 241-257.

Kriesberg, L. (2003). Constructive conflicts: From escalation to resolution. Lanham, MD: Rowman \& Littlefield. 
Kurki, L. (2000). Restorative and community justice in the United States. Crime and Justice: A Review of Research, 27, 235-303.

LaRossa, R. (2005). Grounded theory methods and qualitative family research. Journal of Marriage and Family, 67, 837-857.

Latimer, J., Dowden, C., \& Muise, D. (2005). The effectiveness of restorative justice practices: A meta-analysis. The Prison Journal, 85(2), 127-144.

Liévanos, R. S. (2012). Certainty, fairness, and balance: State resonance and environmental justice policy implementation. Sociological Forum, 27(2), 481503.

Lindsay, M. (2008). Evangelicals in the power elite: Elite cohesion advancing a movement. American Sociological Review, 73(1), 60-82.

Locke, K. (2001). Grounded theory in management research. Sage: London.

Lounsbury, M. (2001). Institutional sources of practice variation: Staffing college and university recycling programs. Administrative Science Quarterly, 46, 29-56.

Lounsbury, M. (2005). Institutional variation in the evolution of social movements: Competing logics and the spread of recycling advocacy groups. In G.F. Davis, D. McAdam, W.R. Scott, \& M.N. Zald (Eds.), Social movements and organization theory (pp. 73-95). Cambridge, U.K.: Cambridge University Press.

Lounsbury, M., Ventresca, M. J. \& Hirsch, P. M. (2003). Social movements, field frames and industry emergence: A cultural-political perspective on US recycling'. Socio-Economic Review, 1, 71-104. 
Maguire, S., Hardy, C., \& Lawrence, T. B. (2004). Institutional entrepreneurship in emerging fields: HIV/AIDS treatment advocacy in Canada. Academy of Management Journal, 47(5), 657-679.

Maney, G. M., Kutz-Flamenbaum, R. V., Rohlinger, D. A., \& Goodwin, J. (2012). Strategies for social change. Minneapolis, MN: University of Minnesota Press.

Martin, P. Y. \& Turner, B. A. (1986). Grounded theory and organizational research. The Journal of Applied Behavioral Science, 22(2), 141-157.

Mauss, A. L. (1975). Social problems as social movements. Philadelphia: Lippincott.

McAdam, D. (1982). Political process and the development of black insurgency. Chicago, IL: University of Chicago Press.

McAdam, D., McCarthy, J. D., \& Zald, M. N. (1996). Comparative perspectives on social movements: Political opportunities, mobilizing structures, and cultural framings. Cambridge: Cambridge University Press.

McCarthy, J. D., \& Wolfson, M. (1996). Resource mobilization by local social movement organizations: Agency, strategy, and organization in the movement against drinking and driving. American Sociological Review, 61(6), 1070-1088.

McCarthy, J. D., \& Zald, M. (1973). The trend of social movements in America: Professionalization and resource mobilization. Morristown, N.J: General Learning Press.

McCarthy, J. D., \& Zald, M. (1977). Resource mobilization and social movements: A partial theory. American Journal of Sociology, 82(6), 1212-1241.

Meyer, J. W. \& Rowan, B. (1977). Institutional organizations: Structure as myth and ceremony. American Journal of Sociology, 83(2), 340-363. 
Michels, R. [1911] (1962). Political parties: A sociological study of the oligarchical tendencies of modern democracy. New York: Free Press.

Minkoff, D. (1993). The organization of survival: Women's and racial-ethnic voluntarist and activist organizations, 1955-1985. Social Forces, 71(4), 887-908.

Minkoff, D. C. (1999). Bending with the wind: Strategic change and adaptation by women's and racial minority organizations. American Journal of Sociology, 104, 1666-1703.

Minkoff, D. (2002) The emergence of hybrid organizational forms: Combining identitybased service provision and political action. Nonprofit and Voluntary Sector Quarterly, 31, 377-401.

Morrill, C. (2006.) Institutional change and interstitial emergence: The growth of alternative dispute resolution in American law, 1965-1995. In W. Powell and D. Jones (Eds.), How institutions change. Chicago: University of Chicago Press.

Morris, A. (1984). The origins of the civil rights movement. New York: Free Press.

Obach, B. (2004). Labor and the environmental movement: The quest for common ground. Cambridge, MA: MIT Press.

O’Brien, S. (2000). Restorative Juvenile Justice Policy Development and Implementation Assessment: A National Survey of States. Ft. Lauderdale, FL: Balanced and Restorative Justice Project, Florida Atlantic University.

O’Brien, S., \& Bazemore, G. (2005). Introduction to the symposium: Communities, organizations, and restorative justice reform. Public Organization Review: A Global Journal, 5, 279-285. 
Osterman, P. (2006). Overcoming oligarchy: Culture and agency in social movement organizations. Administrative Science Quarterly, 51, 622-649.

Piven, F. F., \& Cloward, R. A. (1977). Poor people's movements: Why they succeed, how they fail. New York: Pantheon Books.

Rodriguez, N. (2004). Restorative justice, communities, and delinquency: Whom do we reintegrate? Criminology and Public Policy, 4(1), 103-130.

Rodriguez, N. (2007). Restorative justice at work: Examining the impact of restorative justice resolutions on juvenile recidivism. Crime and Delinquency, 53(3), 355379.

Rucht, D. (1999). Michele's iron law of oligarchy reconsidered. Mobilization, 4(2), 151169.

Santoro, W. A. \& McGuire, G. M. (1997). Social movement insiders: The impact of institutional activists on affirmative action and comparable worth policies. Social Problems, 44, 503-518.

Schneiberg, M. \& Lounsbury, M. (2008). Social movements and institutional analysis. In R. Greenwood, C. Oliver, R. Suddaby, \& K. Sahlin-Andersson (Eds.), The Sage Handbook of Organizational Institutionalism (pp. 648-670). Thousand Oaks, CA: Sage.

Schram, S. F., \& Turbett, P. J. (1983). Civil disorder and the welfare explosion. American Sociological Review, 48, 408-414.

Selznick, P. [1949] (1965). TVA and the grass roots. New York: Harper and Row.

Snow, D. A., \& Benford, R. D. (1988). Ideology, frame resonance, and participant mobilization. International Social Movement Research, 1, 197-217. 
Snow, D. A., Rochford, E. B., Worden, S. K. and Benford, R. D. (1986). Frame alignment processes, micromobilization, and movement participation. American Sociological Review, 51, 464-81.

Soule, S. A. (1997). The student divestment movement in the United States and tactical diffusion: The shantytown protest. Social Forces, 75, 855-83.

Soule, S. A., (1999). The diffusion of an unsuccessful innovation. The Annals of the American Academy of Political and Social Sciences, 566, 120-31.

Soule, S. A. \& King, B. G. (2008). Competition and resource partitioning in three social movement industries. American Journal of Sociology, 113(6), 1568-1610.

Staggenborg, S. (1988). The consequences of professionalization and formalization in the pro choice movement. American Sociological Review, 53, 585-606.

Staggenborg, S. (1991). The pro-choice movement. Oxford: University Press.

Strang, D., \& Soule, S. A. (1998). Diffusion in organizations and social movements: From hybrid corn to poison pills. Annual Review of Sociology, 24(1), 265-290.

Suchman, M. C. (1995). Managing legitimacy: Strategic and institutional approaches. Academy of Management Review, 20, 571-610.

Tarrow, S. (1998). Power in movement: Social movements, collective action, and politics. New York: Cambridge University Press.

Taylor, J. (2007). Organizational elaboration as social movement tactic: A case study of strategic leadership in the first us school-sponsored program for gay and lesbian youth. Social Movement Studies, 6(3), 311-326.

Tilly, C. (1978). From mobilization to revolution. Reading, MA: Addison Wesley.

Tilly, C. (2004). Social movements, 1768-2004. Boulder, CO: Paradigm Publishers. 
Umbreit, M. S., Coates, R. B., \& Vos, B. (2007). Restorative justice dialogue: A multidimensional, evidence-based practice theory. Contemporary Justice Review, $10(1), 23-41$.

Van Dyke, N. and McCammon, H. J. (2010). Introduction: Social movement coalition formation. In N. Van Dyke \& H. J. McCammon (Eds.), Strategic alliances: Coalition building and social movements (pp. xi-xxviii). Minneapolis: University of Minnesota Press.

Van Ness, D., \& Strong, K. (1997). Restoring justice. Cincinnati: Anderson Pub.

Voss, K., \& Sherman, R. (2000). Breaking the iron law of oligarchy: Tactical innovation and the revitalization of the American labor movement. American Journal of Sociology, 106(2), 303-349.

Walker, E. T., \& McCarthy, J. D. (2010). Legitimacy, strategy, and resources in the survival of community-based organizations. Social Problems, 57(3), 315-340.

Wang, D. J., \& Soule, S. A. (2012). Social movement organizational collaboration: Networks of learning and the diffusion of protest tactics, 1960-1995. American Journal of Sociology, 117(6), 1674-1722.

Wood, W. R. (2012). Correcting community service: From work crews to community work in a juvenile court. Justice Quarterly, 29(5), 684-711.

Zald, M. N. (1992). Looking backward to look forward: Reflections on the past and future of the resource mobilization research program. In A. D. Morrils \& C. McClurg Mueller (Eds.), Frontiers in social movement theory (pp. 326-348). New Haven, CT: Yale University Press. 
Zald, M. N. \& Ash, R. (1966). Social movement organizations: Growth, decay and change. Social Forces, 44(3), 327-341.

Zehr, H. (1990). Changing lenses. Scottdale, PA: Herald Press.

Zehr, H. (2002). The little book of restorative justice. Intercourse, PA: GoodBooks.

Zehr, H. (2004). Commentary: Restorative justice: Beyond victim-offender mediation.

Conflict Resolution Quarterly, 22, 305-315. 


\section{APPENDIX A}

\section{Restorative Justice Interview Guide}

1. Tell me about your role and experience with Restorative Justice Louisville.

How did you become involved? And why?

When did you first hear of restorative justice as a practice?

What were your first impressions?

Have those views changed over the last years?

2. Who do you work most closely with in your participation with RJL?

3. How many of the people participating in RJL did you know before your participation in RJL?

Tell me about those relationships--are they family members, friends, or colleagues?

4. Who do you collaborate with in your participation with RJL that you are surprised you work with? (i.e. unlikely characters or people from different fields or offices that you didn't expect to work with?)

5. How do your other affiliations (workplace, other organizations) intersect with your involvement in RJ?

6. When you run into problems or roadblocks, where do you seek assistance or answers?

Do you ever turn to connections outside of RJL?

7. Thus far I've been asking you questions that relate to what the academic literature in this area says is important to the development and sustainability of an organization. But I want to step back a moment and ask you what you think about the questions I've been asking: How important do you think the networks and relationships surrounding RJL are to the sustainability of the organization?

--The next few questions will concern RJL as an organization.

8. Has RJL faced opposition from decision makers within the justice system or from the public?

What did RJL do? (i.e. did you use certain tactics to change minds or gain influence? 
How did they establish legitimacy with these different actors? By legitimacy I mean, seen as valid or credible, in other words, their existence is not constantly questioned or doubted.

If not a lot of opposition, why do you think they've been accommodating?

9. Has RJL directly confronted the practices of the traditional system? (i.e. utilized protesting or other disruptive tactics?)

10. How does RJL want to be viewed by those outside the organization?

Are there differences in the way RJL is viewed by the criminal justice system, the public at large, or any other group?

Are they battling negative perceptions?

How have they overcome them?

11. How much acceptance does RJL need from the public \& justice system in order to endure? (i.e. is the lack of direct opposition enough? Or is your goal to be accepted and well received?)

12. Tell me about a recent or difficult decision RJL had to make.

Can you walk me through the decision-making process?

Did you vote on the decision?

Is this process you described comparable to how most decisions are made or is it unique?

13. Tell me about a time when there was a disagreement in decision-making within the organization.

How was it resolved?

14. Generally speaking, we expect organizational strategies and practices to arise from within the system, but this is not the case in every situation. Can you think of a time when a practice or strategy came about due to the participation or suggestion of an outside community member or funder?

Walk me through how their idea became established in the practice of RJL.

15. Has there been a situation where you felt as though an outside person was surprised by the seemingly unofficial or informal arrangement of RJL? (i.e. surprised they did not have a paid staff or their own building space)

Have such inquiries encouraged changes or restructuring in the organization?

16. Once again, I'd like to pause. I've been asking questions reflecting the academic literature's emphasis on the importance of the structure of an organization. But, I'd 
like to take a moment to step back and ask you if you think these issues, relating to the structure of an organization are important to the sustainability and development of RJL?

17. Where does support for RJL come from—including financial, time, personnel?

Is the funding concentrated to one specific funder?

Where are the volunteers coming from?

Are these one time or ongoing funds or commitments?

How involved are the funders in deciding the direction of the organization?

18. What will be the next step for RJL?

Who's mind will you try to change next?

How will you go about it?

19. Now that I've had a chance to ask you all these questions, what questions am I not asking that I should ask? Is there something concerning the development and sustainability of RJL that my questions have not pursued? 


\section{APPENDIX B}

\section{Restorative Justice Louisville Conference Process}

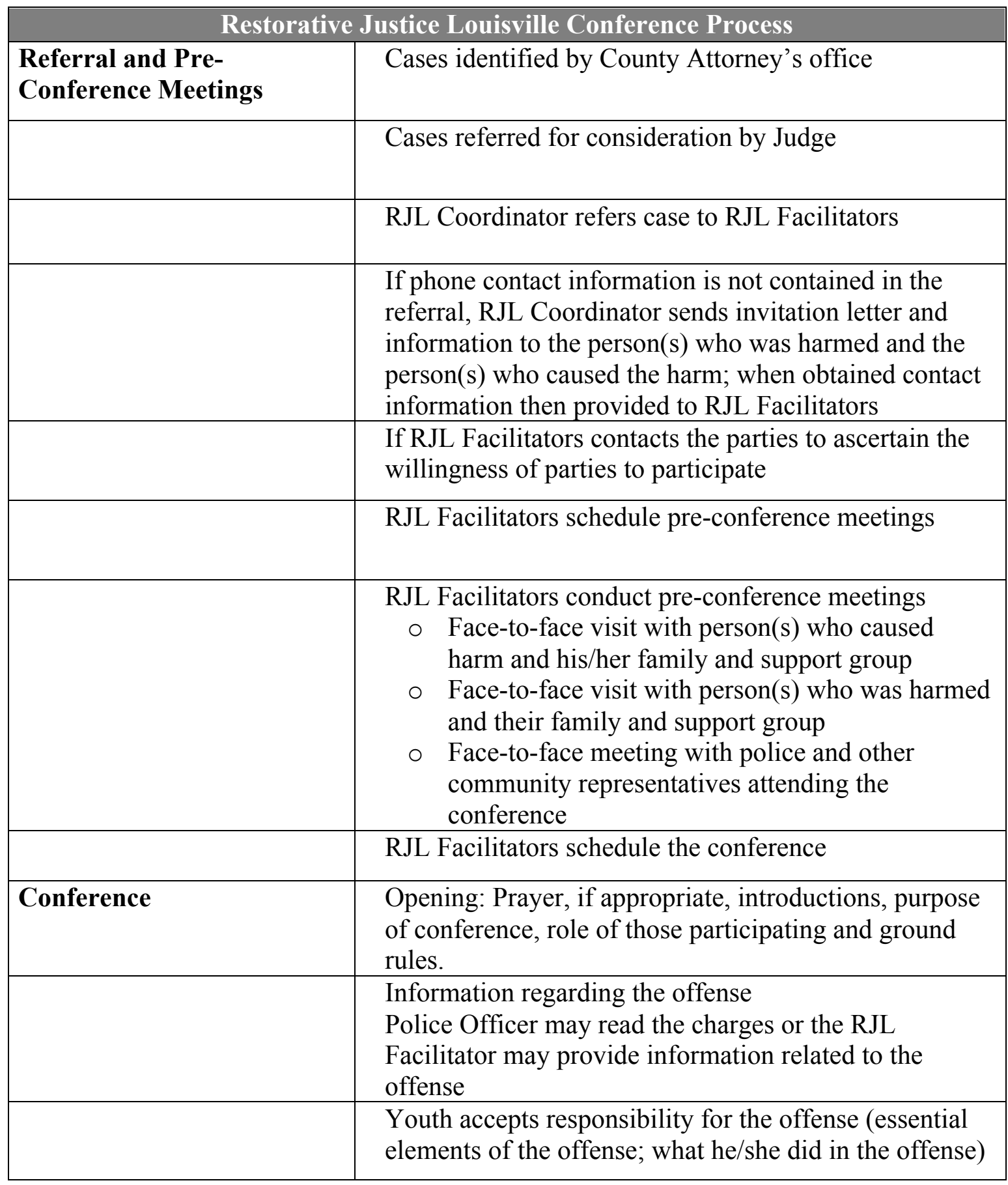




\begin{tabular}{|l|l|}
\hline & $\begin{array}{l}\text { The person(s) who was harmed and support persons } \\
\text { discuss how the offense impacted them; person who } \\
\text { was harmed asks questions }\end{array}$ \\
\hline $\begin{array}{l}\text { Person(s) who caused the harm responds to the questions } \\
\text { and impact of the offense }\end{array}$ \\
\hline $\begin{array}{l}\text { Support person(s) of the person(s) who caused the harm } \\
\text { provide their statement regarding the impact of the } \\
\text { offense }\end{array}$ \\
$\begin{array}{l}\text { Negotiating the agreement. This may be accomplished } \\
\text { through two (2) different processes. They are: } \\
\text { 1. Break (caucus) where person(s) who caused the } \\
\text { harm, family members and support persons develop } \\
\text { proposal for agreement separately, present it to the } \\
\text { conference the person(s) who was harmed and the } \\
\text { other participants for suggestions and agreement; or } \\
\text { 2. Continue with the conference and with input from } \\
\text { all, and emphasis on person(s) who caused harm } \\
\text { and person(s) who was harmed, develop the } \\
\text { agreement }\end{array}$ \\
\hline $\begin{array}{l}\text { Plan is agreed to (consensus) and recorded by the } \\
\text { facilitators }\end{array}$ \\
\hline $\begin{array}{l}\text { Conference is closed } \\
\text { RJL Facilitators debriefing } \\
\text { RJL follow-up with person(s) who was harmed to } \\
\text { determine if further services are needed } \\
\text { RJL monitoring of the agreement } \\
\text { RJL Case closure }\end{array}$ \\
\hline Post-Conference
\end{tabular}




\title{
CURRICULUM VITAE
}

\author{
BRITTANY BUTTRY-WATSON \\ Department of Sociology \\ University of Louisville \\ Louisville, KY 40292 \\ b.buttrywatson@louisville.edu
}

\section{EDUCATION}

M.A., Department of Sociology, University of Louisville (2014)

B.S., Social Work, Greenville College, Greenville, Illinois (2009)

B.A., Psychology/Religion, Greenville College, Greenville, Illinois (2009)

\section{TEACHING EXPERIENCE}

Graduate Teaching Assistant, University of Louisville, Department of Sociology, Introduction to Sociology (Fall 2012 to Spring 2014)

Graduate Teaching Assistant, University of Louisville, Department of Sociology, Online--Introduction to Sociology (Spring 2013 to Fall 2014)

Graduate Teaching Assistant, University of Louisville, Department of Sociology, Honors--SOC 201 Introduction to Sociology (Fall 2012, Spring 2014)

\section{RESEARCH EXPERIENCE}

Research Team, Brandon McReynolds' Master's Thesis, University of Louisville "Informal Study Groups: Gender \& Group Homophily" (Spring 2014)

Research Assistant, University of Louisville, Department of Sociology "Using Photography in the Classroom to Facilitate Critical thinking" (Spring 2014)

Graduate Research Assistant, University of Louisville, Department of Sociology (Fall 2012 to Spring 2013)

Field Research Assistant for The National Institute of Health, University of Louisville, 
Department of Communications "Exploring Culture, Community,

Communication, and Fruit and Vegetable Intake in Black Kentuckians" (Summer 2012)

\section{SCHOLARSHIP}

Taniguchi, H., \& Buttry-Watson, B. (June 25, 2013). Japanese Citizen Participation in International Development Aid. Voluntas: International Journal of Voluntary and Nonprofit Organizations, 25(91), 1990-2014.

Buttry-Watson, B. \& Austin, M. (August, 2013). Fostering Critical Thinking: A Compilation of Course Materials in Introduction to Sociology. Best practices manual created for Ideas to Action, University of Louisville.

\section{TRAINING \& CERTIFICATION}

TESL Certified, Greenville College (May 2009)

Restorative Justice Facilitator, Louisville, KY (August 2013)

Graduate Teaching Academy, University of Louisville (Fall 2012-Spring 2013)

\section{HONORS \& AWARDS}

Outstanding Teaching Award, University of Louisville (April, 2014)

Presidential Citation Award, Greenville College, Greenville, IL (May, 2009)

Summa Cum Laude, Greenville College, Greenville, IL (May 2009)

Dean's List (eight consecutive semesters), Greenville College, Greenville, IL

\section{SERVICE}

Sociology Graduate Student Association Treasurer, University of Louisville (2013-2014)

Graduate Student Council Representative, University of Louisville (2013-2014)

\section{WORK EXPERIENCE}

OHIO UNIVERSITY EDUCATION ABROAD—Athens, OH Administrative Assistant

(Fall 2011-Fall 2012) 
- Facilitated the daily work of six student workers, aided faculty directors with travel preparation, updated website, managed online and paper systems, assisted students in planning and arranging study abroad travel

GOOD EARTH FARM-Athens, OH

(Fall 2010-Fall 2011)

Produce Distribution Coordinator

- Assisted with garden work, maintained farm grounds, coordinated distribution of food to local shelters, scheduled volunteers, collaborated with other members to implement financial and structural strategies, planned programs \& fundraisers

LAPUENTE-Alamosa, CO

(Fall 2009-Fall 2010)

Caseworker

- Supported clients in obtaining proper care \& resources, worked with under or non-insured persons seeking dental or optical attention, aided clients in obtaining appropriate identification (drivers licenses, birth certificates, S.S. cards), supported housing and energy staff in assisting clients, managed paper and online information systems, planned and executed community programs

GREENVILLE COLLEGE—Greenville, IL

(Fall 2008-Summer 2009)

Alumni Staff

- Facilitated communication between alumni and the university, prepared current students to maintain a role in the alumni community, assisted with mailings, performed secretarial duties, planned programs and gatherings for alumni, and acted as a voice for the office 